\title{
Archaeological Fieldwork on Norfolk Island
}

\author{
Atholl Anderson, ${ }^{1}$ IAn Smith ${ }^{2}$ And Peter White ${ }^{3}$ \\ ${ }^{1}$ Department of Archaeology \& Natural History, Research School of Pacific and Asian Studies, \\ Australian National University, Canberra ACT 0200, Australia \\ aja@coombs.anu.edu.au \\ ${ }^{2}$ Department of Anthropology, University of Otago, Dunedin, New Zealand \\ ian.smith@stonebow.otago.ac.nz \\ ${ }^{3}$ Archaeology, University of Sydney, Sydney NSW 2006, Australia \\ Peter.White@antiquity.usyd.edu.au
}

\begin{abstract}
Exploratory excavations in Cemetery, Emily and Slaughter Bays in search of a prehistoric settlement site are outlined, along with small scale researches elsewhere on Norfolk Island and on adjacent islands. The archaeological excavations at the settlement site discovered in Emily Bay are described in detail and the taphonomy of the site discussed.
\end{abstract}

Anderson, Atholl, Ian Smith And Peter White, 2001. Archaeological fieldwork on Norfolk Island. In The Prehistoric Archaeology of Norfolk Island, Southwest Pacific, ed. Atholl Anderson and Peter White, pp. 11-32. Records of the Australian Museum, Supplement 27. Sydney: Australian Museum.

The Norfolk Island Prehistory Project (NIPP) programme was divided into four field seasons. These were in December 1995 (directed by Atholl Anderson and Geoff Hope), in April 1996 (directed by Atholl Anderson and Ian Smith), in November 1997 (directed by Atholl Anderson and Peter White) and in February 1999 (directed by Peter White). It is convenient to describe the fieldwork and the characteristics of the sites investigated in this framework.

\section{Fieldwork in 1995}

Cemetery Bay. The first focus of fieldwork on Norfolk Island was upon the fauna-rich localities previously recorded in Cemetery Bay. It was considered that further investigation of these might divulge clues to a greater cultural influence in the evidence than was then known, essentially the existence of rat bone and charcoal. Local resident Jack Anderson took us to a place located $78 \mathrm{~m}$ south of the southern end of the Cemetery Bay sand beach ("Jack's site"). There are similar exposures, many disclosing faunal material, to either side, but this one had the deepest stratigraphy. At the top of the low cliffs (about $5 \mathrm{~m}$ above high tide level) were two sedimentary units resting in holes and crevices of the underlying calcarenite basement. The upper consisted of about $0.5 \mathrm{~m}$ of coarse yellow-brown sand, containing scattered pebbles, calcarenite rubble, landsnails and bones, while the lower consisted of up to $0.5 \mathrm{~m}$ of compacted brown sand and clay, full of calcarenite rubble, and with very little bone. Most of the bone came from a band $0.1-0.5 \mathrm{~m}$ below the surface. A small excavation of the exposed face and of material slumped from it was carried out, and the faunal remains retained for analysis. There was nothing about them to suggest a cultural origin.

Trench CB95:01. The "Old Quarry" site ("Area 1" of Varman, 1990) at Cemetery Bay was chosen for investigation because it was the locality in which unit $\mathrm{C} 4$ (a band of charcoal enriched sand, and bird, fish and rat bones) had been most extensively investigated (Anderson and White, Approaching the Prehistory, this vol.). A large shell adze had been found in the northwest corner of the "Old Quarry" 
during sand mining. A $3 \mathrm{~m}^{2}$ trench (CB95:01) was excavated in undisturbed ground near the edge of the quarry, some 5$8 \mathrm{~m}$ away from where the adze had been picked up (Fig. 1, further details in Anderson, 1996).

The stratigraphy at this site consisted of layers of carbonate sand interleaved with layers of sand or siltenriched clay (Fig. 2). The upper of these latter formed part of the current soil horizon (included for archaeological recording purposes in layer 1), and the others were designated layers 2, 4 and 6 . The important point to note about these layers is that they are not palaeosols. There is no evidence of soil development. Rather the material appears to have been washed into the site where it makes a sharp contact with the sand beneath (except for some subsequent worm activity, especially at the base of layer 6 ), and lifts away from it cleanly. In each case, the clay and silt has also carried pumice, which is found particularly in the upper parts, and on top of, each clay layer. The probable source of the clay is slope wash from the nearby hills.

The discovery of a concentration of rusted iron nails in layer 4 indicates that the top $0.65 \mathrm{~m}$ of the site, including the upper three clay layers at least, are European. The sand in layer 7 contained an irregular depression in the upper surface, filled with layer 6 clay, which might be an old root

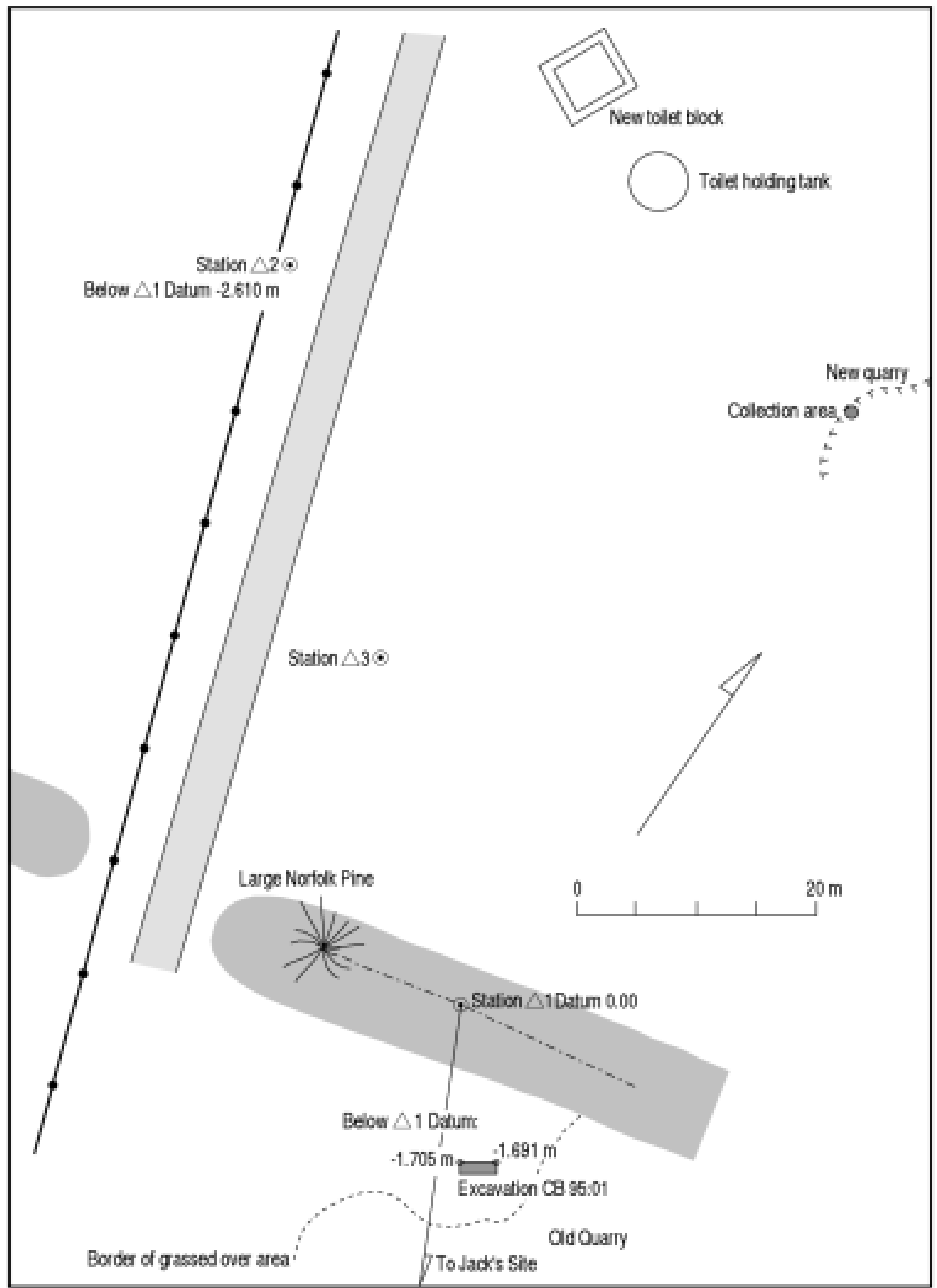

Figure 1. Location of trench CB95:01 in Cemetery Bay. 


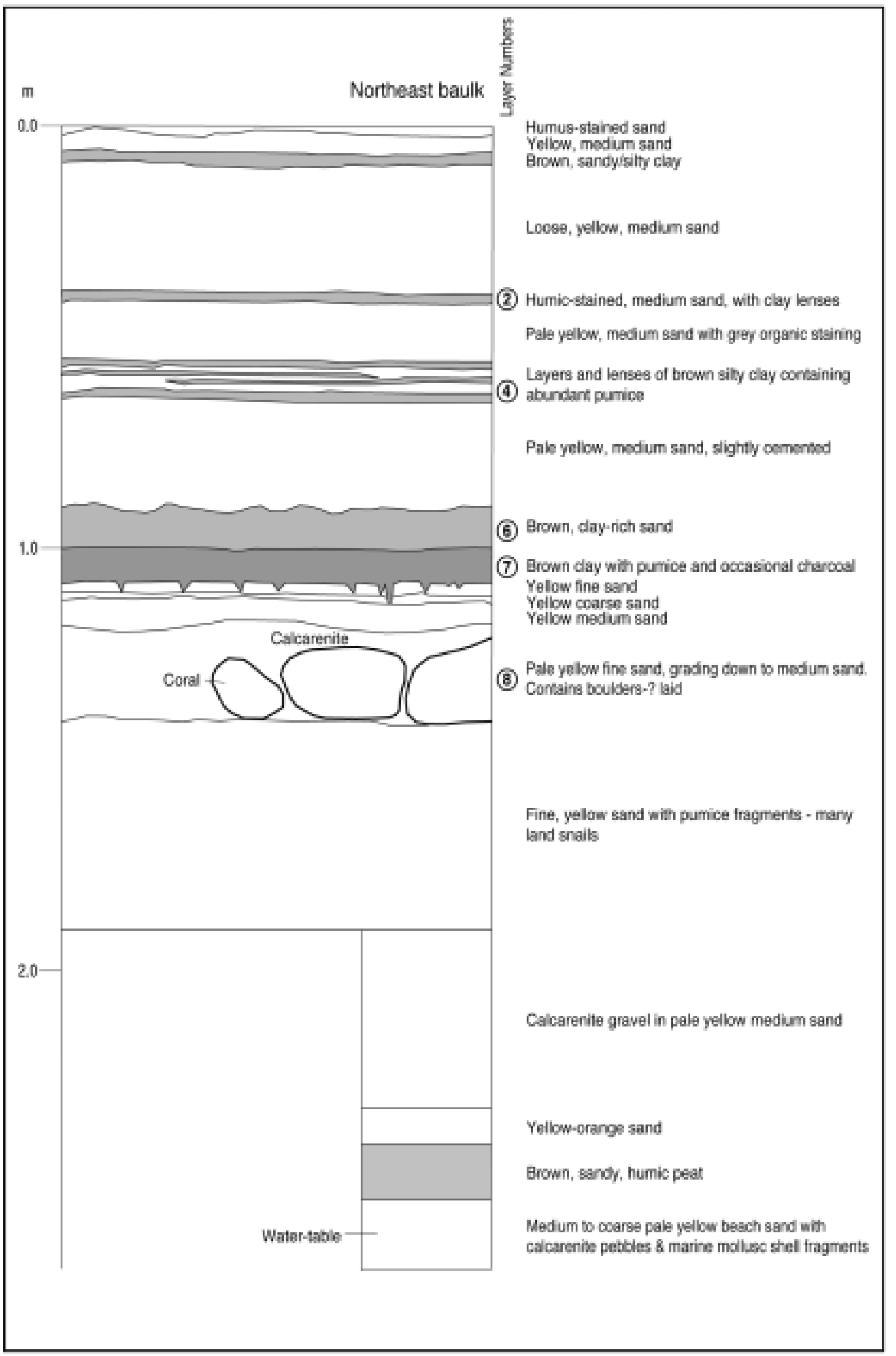

Figure 2. Stratigraphy of trench CB95:01 in Cemetery Bay. 
channel, or possibly a procellariid burrow, but neither need be prehistoric. There was a noticeable increase in the abundance of charcoal and fish, bird and rat bones in layer 7, which appears in this respect, and in depth, to correspond with unit C4 (Meredith et al., 1985), but the layer of calcarenite and coral boulders in layer 8 seems to have been laid by hand. It may form the edge of a coastal road known to have run through Cemetery Bay during the convict era. In that case, all of the stratigraphy down to at least $1.40 \mathrm{~m}$ is European in age.

This has important implications for the discovery of an adze nearby, “... the only artefact found on Norfolk for which a sub-surface context has been proposed" (Specht, 1993: 153). The adze, of Tridacna gigas shell, does not appear to be of Polynesian provenance and might have been imported from Melanesia, possibly in the nineteenth century, after the establishment of the Melanesian Mission in 1866. It was associated with a beer-barrel conch shell, a local species, when found by Ted Clampett and Matti Nola in December 1984. Information in the Norfolk Island Museum (Bag with conch shell, labelled ARNI 7), indicates that the findspot was $1.5 \mathrm{~m}$ below the surface (Specht, 1993: 150, quotes Varman as indicating a depth of 1.25-1.5 m), in clean yellow, sand. This would put it in the upper part of our layer 8 which is possibly very late prehistoric or European in age. It would then follow that the stratigraphy in our trench and its vicinity, possibly through European disturbance, is not the same as that which Meredith et al. (1985), excavated approximately $100 \mathrm{~m}$ away and dated to 800-700 B.P.

A sample of Rattus exulans bone collected by Charles Meredith from 140-155 cm in unit C4 was provided by the Museum of Victoria and we submitted it to the Oxford Radiocarbon Accelerator Unit. A sample of Rattus exulans bone from 130-150 cm depth in CB95:01 was submitted for radiocarbon dating at the Rafter Laboratory, Institute of Geological and Nuclear Sciences, Lower Hutt. The results, respectively OxA5781 and NZA6635, are presented in Anderson, Higham and Wallace, this vol., Table 8.
Trench CB95:02. At the request of the Kingston and Arthur's Vale Heritage Association and the Norfolk Island Administration, the excavation of a pit, about $5 \mathrm{~m}$ in diameter, for the toilet holding tank at Cemetery Bay was monitored and faunal material recovered as it became exposed by hand digging. The stratigraphy was as follows: $1.0 \mathrm{~m}$ of buff dune sand, then $0.45 \mathrm{~m}$ of medium-coarse, yellow-brown calcareous sand, containing an occasional bird bone. Below this was $0.7 \mathrm{~m}$ of brown sandy clay containing some bird bones and fragments of pumice, overlying $0.3 \mathrm{~m}$ of a coarse pale-yellow to white sand. This graded down into a white sand with many lumps of calcarenite, water-rolled marine shells and some fossil wood. Left to stand, the pit filled with fresh water to the top of the pale-yellow sand.

Cemetery Bay Stratigraphy. The previous excavations in this area leave little doubt that at least some of the material has a cultural origin (Anderson and White, Approaching the prehistory..., this vol.). While our research did not uncover any more conclusive evidence than that already established, we think that the wide distribution of charcoal, including a burnt stump, and its stratigraphic correspondence with Rattus exulans bone, define an horizon which is essentially cultural. Quite probably it is either on the periphery of a settlement site or it was an area of forest clearance.

Emily Bay. Attention turned to Emily Bay because it has produced a quantity of adzes and waste flakes over the years (Anderson and White, Approaching the prehistory..., this vol.) and it is inherently more suitable for prehistoric settlement than anywhere else on Norfolk Island. It provides the most sheltered anchorage for small craft and the best beach from which to launch and recover canoes. It is at the centre of the broad band of intertidal reef which runs from Cemetery Bay to Slaughter Bay, and at the broadest end of the lagoon, providing unparalleled access to inshore marine resources. Small vessels, including canoes, can cross the reef at high tide and, prior to the construction of the Kingston jetty, it was possible to sail into the western end of the lagoon and along to Emily Bay (Figs. 3, 4).

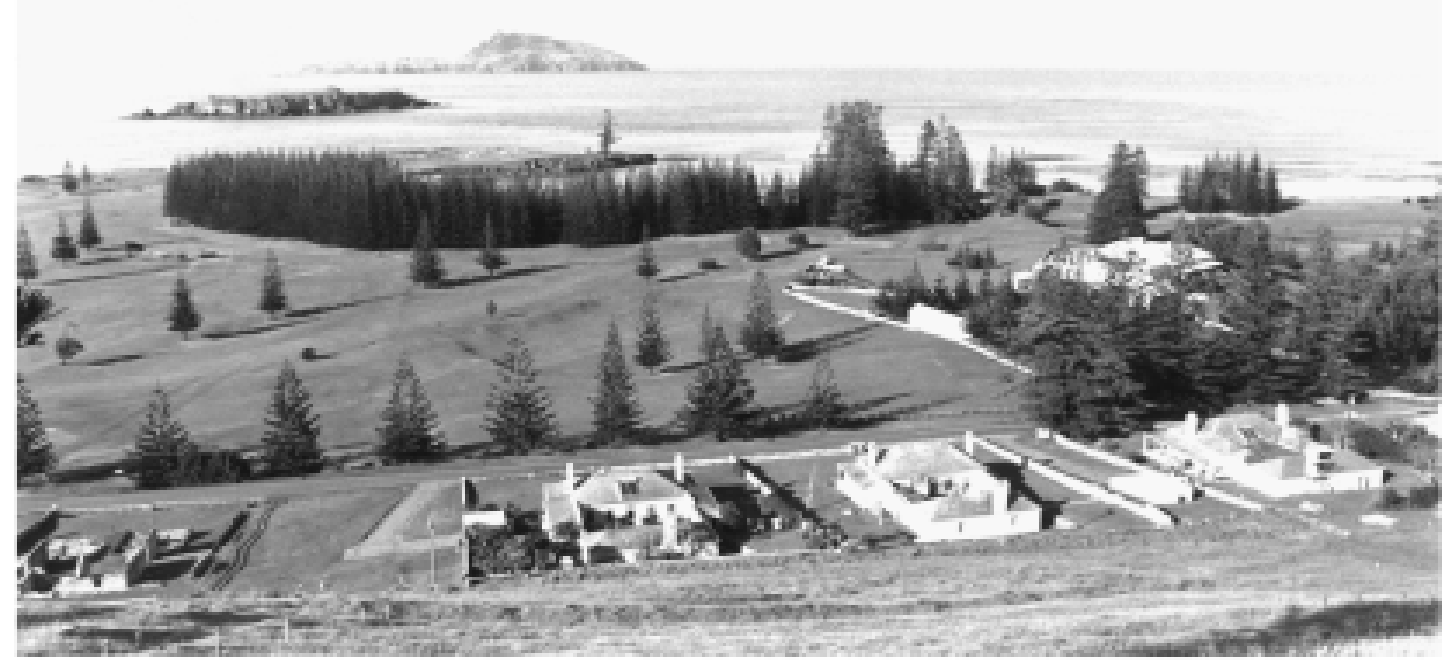

Figure 3. Emily Bay sheltered by a Norfolk pine plantation, with Slaughter Bay to the right. The main excavations occurred towards the right hand end of the main plantation of Norfolk pines. Nepean and Philip Islands in the background. 


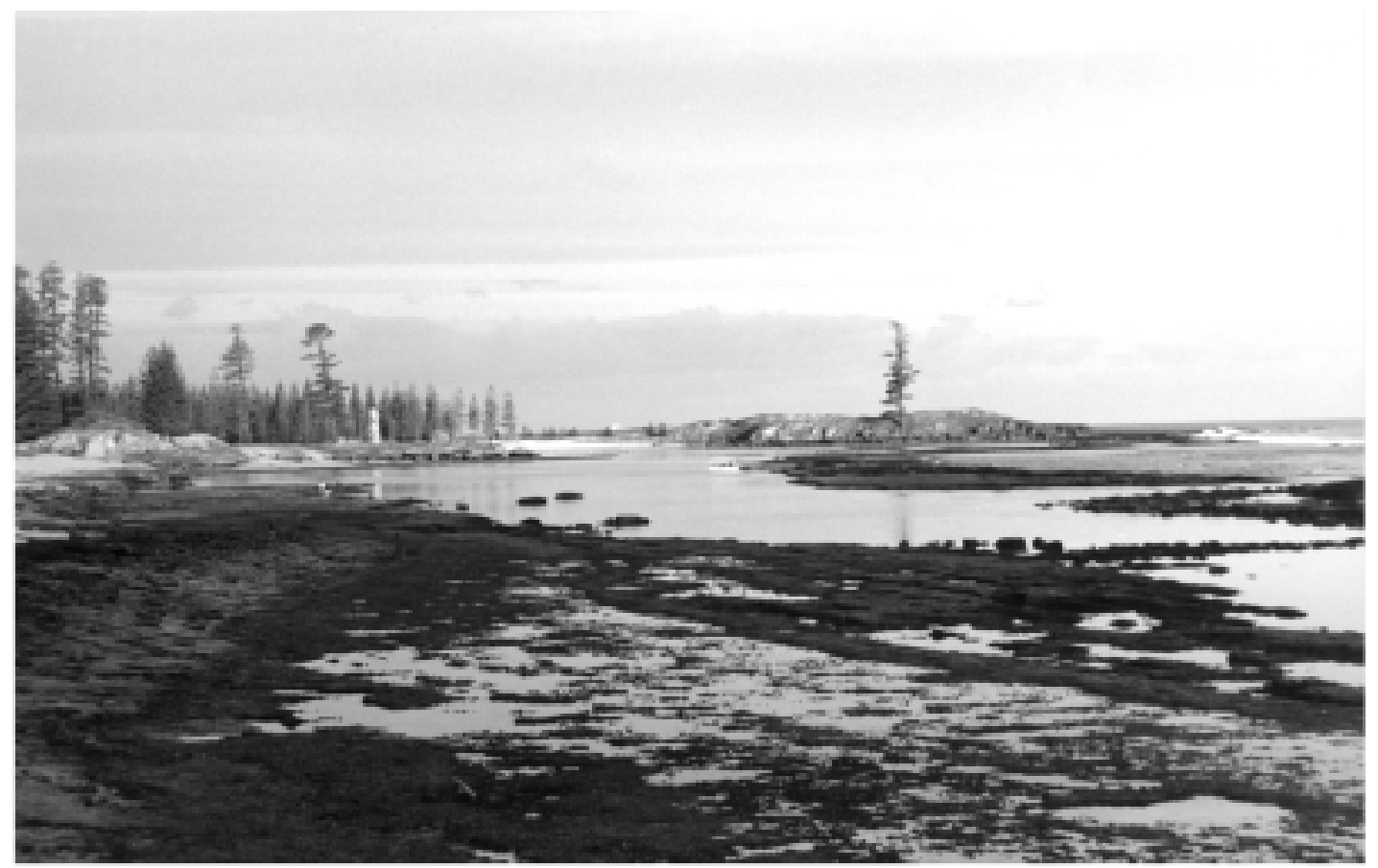

Figure 4. The reef in Slaughter Bay at low tide. Emily Bay is in the background, behind the limekiln chimney.

Search procedure. After inspecting the exposures in the drain and road cuttings, some auger holes were drilled and two road sections cleaned down in the Eastern end of Emily Bay, without discovering any archaeological remains. It was then decided to employ a small mechanical digger to explore the sand dune stratigraphy in greater depth. The first trench (EB95:01) was dug $115 \mathrm{~m}$ east of the toilet block and $5 \mathrm{~m}$ south (i.e. seaward) of the present road. It was located $8 \mathrm{~m}$ east of the exposed remains of an historical (A.D. 1835) road. A trench of $1.5 \times 1 \mathrm{~m}$, narrowing to about $1.0 \times 0.5 \mathrm{~m}$ at the bottom ( $2.5 \mathrm{~m}$, about the level of the modern road surface) was taken out in approximately $0.2 \mathrm{~m}$ spits. The stratigraphy consisted of medium to fine, yellow, carbonate sand, slightly compacted. There were occasional pieces of water-rolled pumice, but none in bands. (All sands in this and other trenches were described by ANU geomorphologist, Prof. G. Hope). No sign of cultural material was noted.

Directly inland across the road, there is a sand quarry area which has been scraped down to the level of the road surface. It is now partly used as a gravel dump and parking area. In this area, 13 m north of Trench EB95:01 a second trench (Trench EB95:02), was dug in the same way and of the same dimensions. At the top of it was a $0.15 \mathrm{~m}$ thick brown clay packed with road gravel, and evidently the edge of the modern road base. Beneath it, was a $0.7 \mathrm{~m}$ deep unit of yellow carbonate sand as in Trench EB95:01, lying above $0.1 \mathrm{~m}$ of bright yellow-orange sand and then fine white sand saturated with fresh water. The water table stood at the junction of the latter two units and along it was found matted roots of Araucaria. No sign of cultural material was noted. Another trench (EB95:03) was dug approximately $36 \mathrm{~m}$ northeast of Trench EB95:02. This disclosed the same stratigraphy as in Trench EB95:01, that is medium to fine yellow carbonate sands containing occasional small pieces of water-rolled pumice. No cultural material was noted.

The digger was then moved to the western end of Emily Bay within a fenced-in Norfolk pine plantation (Figs. 3, 5).
Local historians believe that there may be some early historical burials in this general area, and particular attention was paid to any signs of those (none were observed, and some evidence suggests that the burial area was seaward of the present road (Specht, 1984: 32)). An auger hole revealed no cultural material, and the digger was employed. In order to get a shallower scrape of $0.1 \mathrm{~m}$ per time, a trench $2.5 \times 1.0$ $\mathrm{m}$ at the top, narrowing to $1.8 \times 0.7 \mathrm{~m}$ on a sloping base (Trench EB95:04), was excavated. The sand below the pine duff was as in Trench EB95:01, but with occasional brown mottles. At $0.7 \mathrm{~m}$, in the western end of the trench a sand of the same type, but light grey in colour appeared. A surface of grey sand was then exposed by trowel, the sterile overburden being cleared periodically by the digger. The surface proved to slope steeply to the east and was discontinuous in plan (Fig. 6). Excavation of part of this feature by trowel disclosed a broken cobble of basalt, several small fragments of charcoal and two large fish spines. This was taken as being the remains of an Oceanic type of cooking area and thus prima facie evidence of a prehistoric settlement site.

Nicolai records. Our discovery prompted local resident and archaeologist Mr Bevan Nicolai to produce a sample of bone collected from West Emily Bay in which some material appeared to be of cultural origin (remains of large fish, broken bones of large birds, a dog mandible). It is apparent, in fact, that Mr Nicolai (n.d.) had come very close to deducing the existence of a prehistoric site in Emily Bay. In November 1986 the Norfolk Island Administration dug a longdrop toilet hole (subsequently unused) just outside the seaward plantation fence in Emily Bay, about $15 \mathrm{~m}$ west of the gate. This produced the material noted above, plus some rat bones and basalt flakes. In his field notes (26 November 1986) Mr Nicolai observed that the fish bone was too big to have been washed up or brought by birds and he was curious about the dog bone. He concluded that only some radiocarbon determinations might solve the puzzle. 


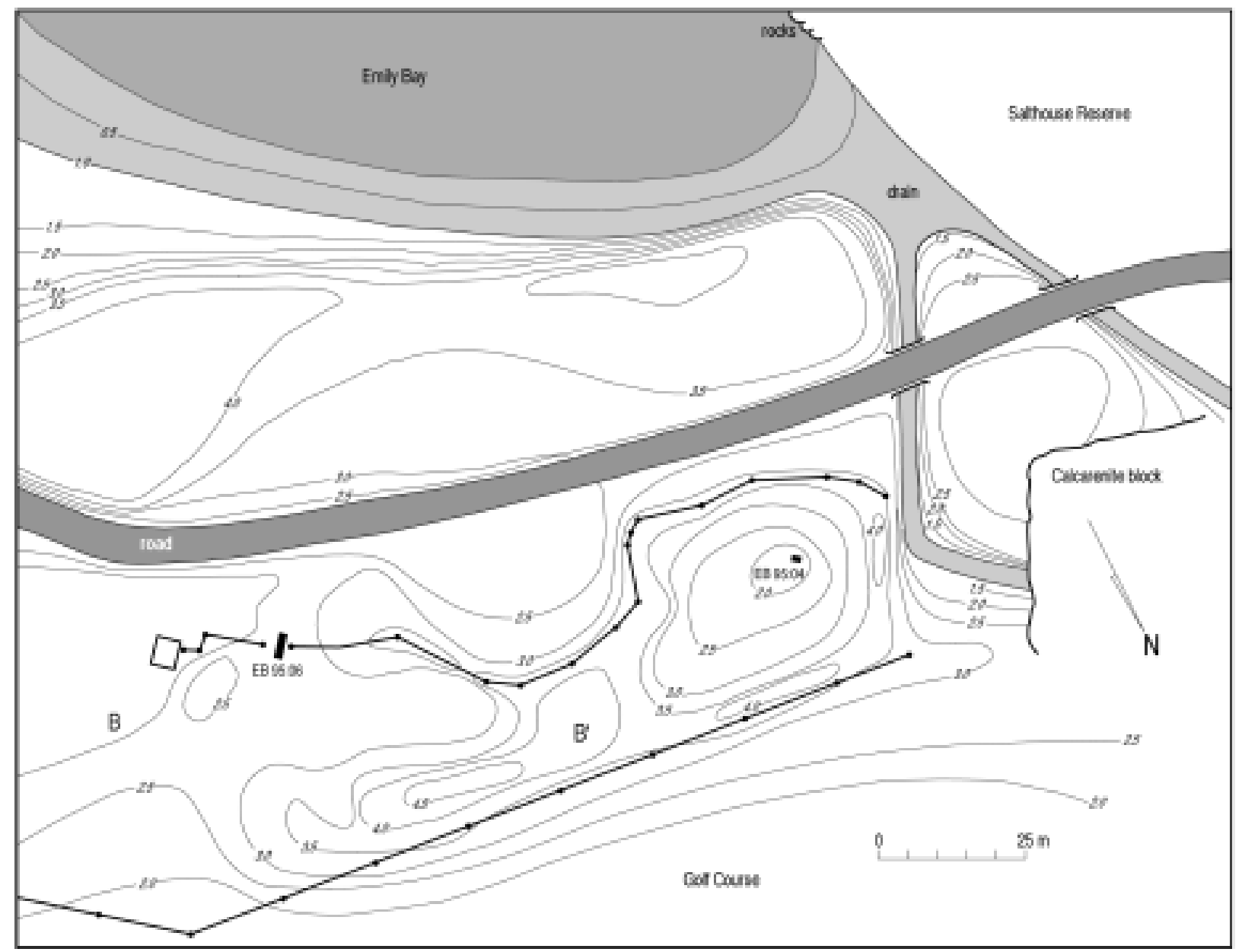

Figure 5. Location of Trenches EB95:04 and EB95:06 (incorporating EB95:05) at Emily Bay in 1995.

Similarly, in April 1987, Mr Nicolai (n.d.) recorded the existence of bird, rat and fish bones eroding from the sand face under the old convict road at the extreme eastern corner of Slaughter Bay, noting again that the fish bone must have come from individuals too large to have been carried by birds. He excavated about $0.5 \mathrm{~m}$ into the face and collected some faunal material. In 1995, he found an adze in the sand near this place.

While inspecting the ground surface in the vicinity of the Emily Bay toilet block, bird bone fragments and some fish bones were noted around the base of fence posts near the gate, at the gate posts, and on the sand road surface near the toilets. An auger hole near the fence (Fig. 8, Auger hole 3) encountered a brown clay soil at about $0.7 \mathrm{~m}$ and then some grey sand. No faunal or cultural remains were recovered, but the sand looked like that in EB95:04, so it was decided to concentrate attention in the vicinity. A testpit of 0.4×0.4 m (Trench EB95:05) was then excavated, which disclosed cultural stratigraphy (Fig. 7), a broken and apparently burnt piece of a basalt cobble and a struck basalt flake. Some bird, fish and rat bone was recovered, along with small pieces of charcoal.

Trench E95:05 was then enlarged to an excavation of 4.0×1.0 m (Figs. 8, 9), called Trench EB95:06, which was set out across the gate opening. The digger was employed to remove loose dune sand and roots from above the claythe latter, tough and sticky, was chipped off by hand. Underneath the clay was a surface of dark grey sand.
Excavation showed that this dark grey sand formed a single layer and the material was taken out in four spits. All material was passed through $4 \mathrm{~mm}$ sieves. Initially we tried $2 \mathrm{~mm}$ mesh but found that it collected too much extraneous material, even when washed through, particularly rootlets which were abundant in the sand. Collection of material passing through the $4 \mathrm{~mm}$ mesh showed that some small pieces of broken bone and small landsnail shells (very common in all sand deposits on the island) were being lost, but not identifiable material of cultural origin (this was checked regularly by palaeontologist, Richard Holdaway, who took samples).

Two earth ovens were found, each consisting of a shallow scoop in which were packed burnt and broken fragments of basalt cobbles, charcoal pieces and bird, rat and fish bones, often broken and some burnt. One oven lay somewhat higher than the other in the same layer, and some material had spilled from each into the surrounding area. Six flakes of struck basalt were recovered, several of them of distinctive forms created in the fashioning of adze preforms. No other structures or artefacts were noted. The stratigraphy suggests a single cultural phase, probably of limited duration (Anderson, 1996).

Judging by our auger holes (Fig. 8, Auger holes 1-4), there is one edge of the Emily Bay site between the gateway and the northern wall of the toilet block, although the recovery of bones during the digging of the toilet pit indicates that the site extends that far. The stratigraphy in 


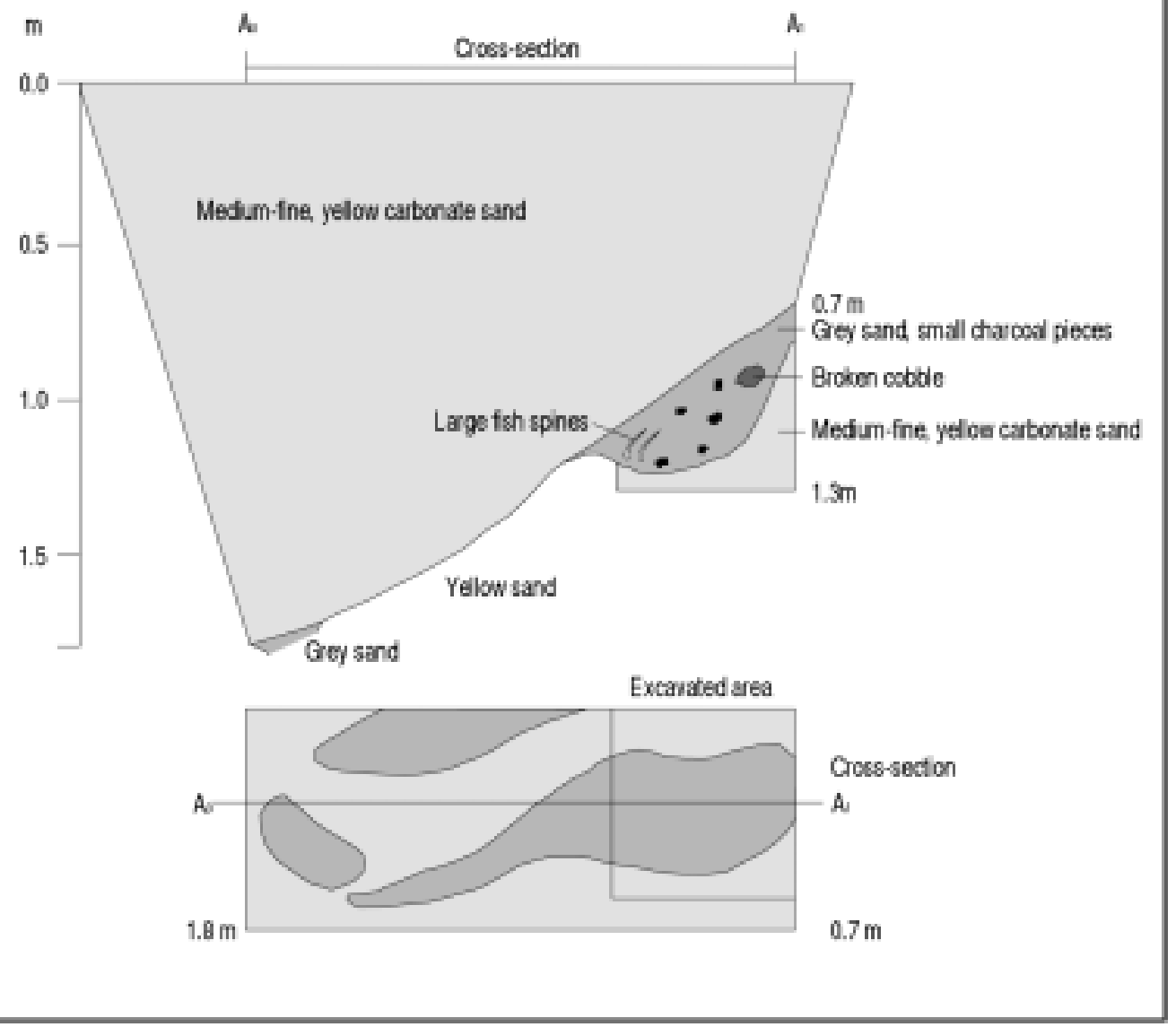

Figure 6. Stratigraphy and cross-section of Trench EB95:04.

Trench EB95:06 shallows towards the south, possibly indicating that there is another margin to the site between the gateway and the sealed road.

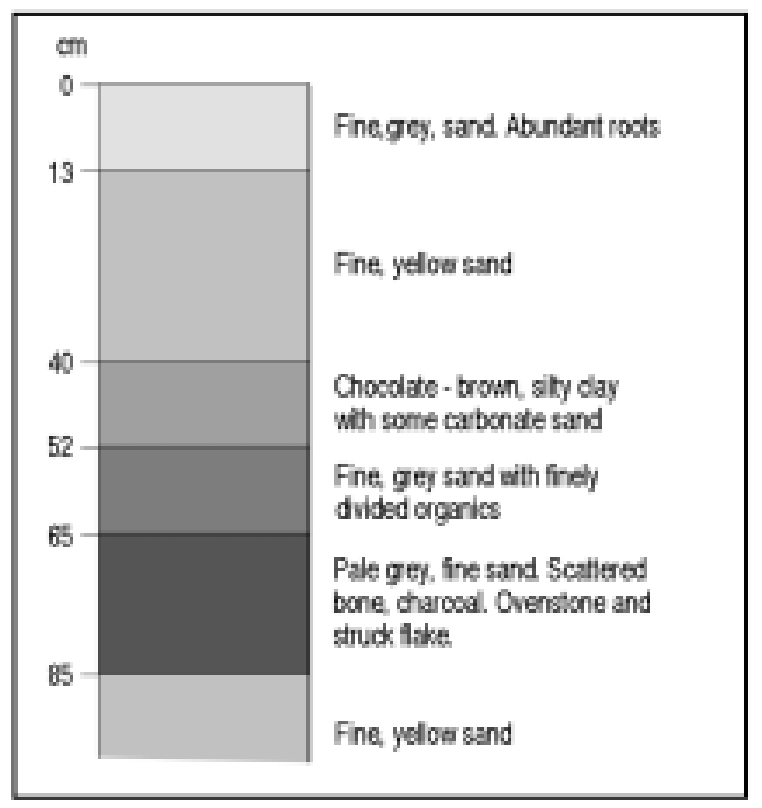

Figure 7. Stratigraphy of Trench EB95:05.

\section{Fieldwork in 1996}

Slaughter Bay. Investigations were confined to the eastern end of the bay, on the assumption that, since this was the end nearest to the known site in Emily Bay, and also the locality in which most of the adzes and adze pieces of Polynesian type had been found (Specht, 1984), it was the most likely area to produce prehistoric archaeological stratigraphy.

Search procedure. A series of holes was drilled with the sand auger along the northern side of the road at about 15 $\mathrm{m}$ intervals between the calcarenite massif and the western end of the stand of pines, and then north-south between the drain and the sea wall. Many of these holes bottomed out at $30-60 \mathrm{~cm}$ on coral rubble and were thus inconclusive. Those which disclosed greater depth and diversity of stratigraphy were noted for further reference and are shown in Fig. 10 (Auger holes a-e).

Test-pits were dug by spade at SB96:01 and SB96:02, but these also encountered difficulty in shifting calcarenite and coral rubble. Consequently, the backhoe was employed to excavate four small trenches: SB96:03 (which incorporated test-pit SB96:01), SB96:04, SB96:05 (which incorporated test-pit SB96:02) and SB96:06. Each trench was approximately $1.5 \times 0.8 \mathrm{~m}$ in area at the top, narrowing to about $0.7 \times 0.5 \mathrm{~m}$ at the bottom of the reach on the hydraulic arm. The sand auger was used in the base of three trenches to investigate the lower sediments. In trench 


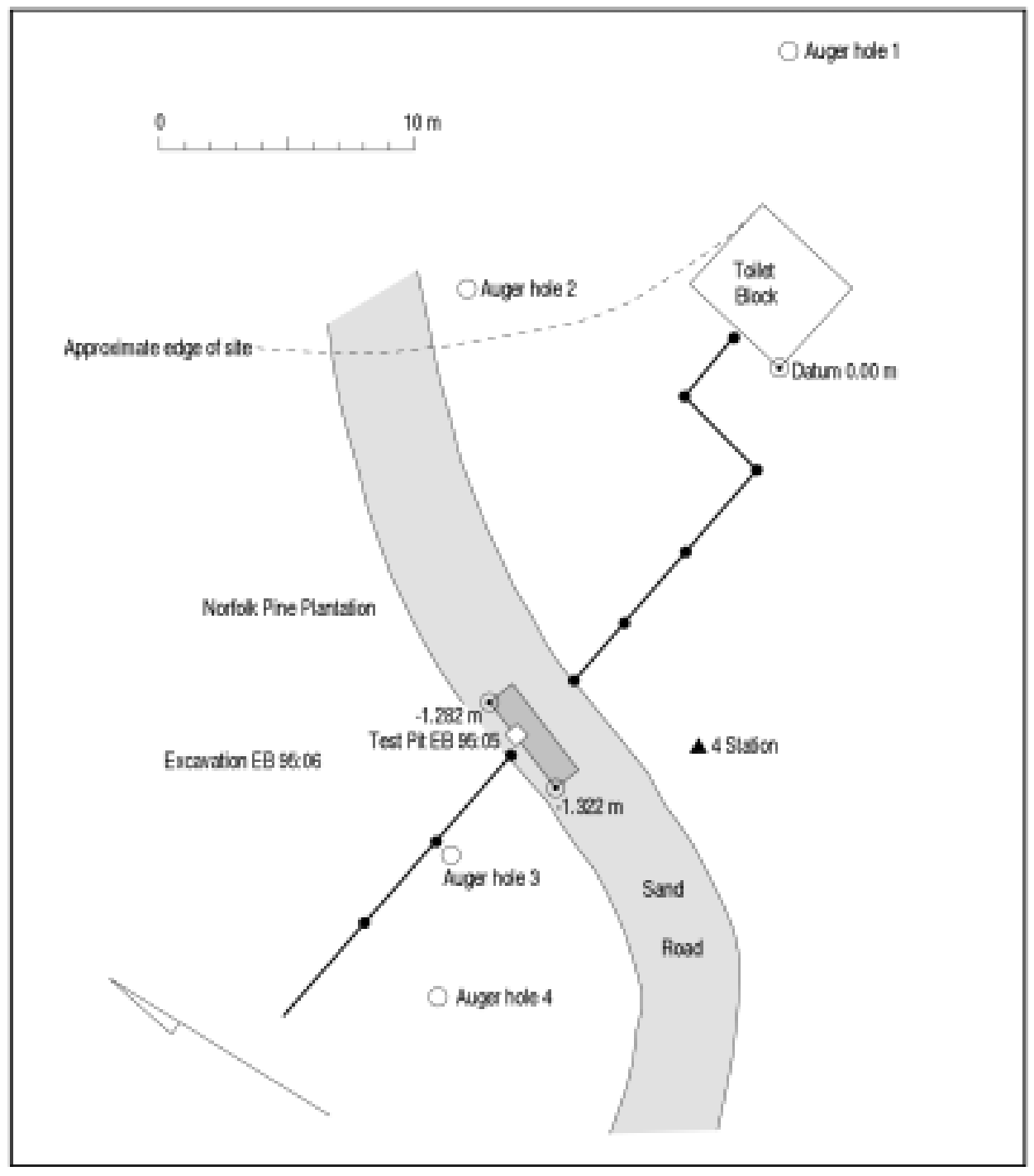

Figure 8. Location of auger holes (labelled 95/1-4 in Fig. 13) and Trenches EB95:05 and EB95:06.

SB96:04, the density of rubble prevented the back hoe from reaching below $1.4 \mathrm{~m}$, and it was not possible to operate the auger. Sections were cleaned down by trowel and the stratigraphy measured and drawn (Fig. 11).

Test Trenches SB96:03-06. No significant cultural remains were revealed, either in structures or artefacts, and no charcoal-enriched levels were recorded. No structures of placed rock or other indications of settlement features of pre-European provenance were observed, except in SB96:06, and possibly SB96:05.

In SB96:03, a broken basalt cobble was found immediately below the brown sandy clay and rock layer, and a small, struck basalt flake, picked out of the sand scoop, seems to have been associated with it. It is possible that both are of historical age and caused incidentally in the course of activities other than adze manufacture. However, it is also possible that the yellow medium calcareous sand and rock unit in which these occurred, along with some pieces of marine gastropod shell and coral is, in fact, the prehistoric settlement level in Slaughter Bay. There was nothing beneath that level of archaeological interest all the way down to the water table at $3.0 \mathrm{~m}$.

Trench SB96:04 was on the top of the ridge near the road. Below a series of thin sand layers of differing characteristics, and a brown, sandy, clay was yellow calcareous sand which, as the trench deepened, proved to contain increasing quantities of calcarenite rubble. This was of all sizes and shapes, in pieces up to $0.8 \mathrm{~m}$ long, with sand between. It has the appearance of a storm beach layer and may lie immediately above solid calcarenite bedrock.

Trench SB96:05 disclosed a thin layer of partly burnt packed calcarenite rubble lying above a thicker layer of calcarenite rubble and sand. Since the trench was dug beyond the known boundary of the convict road, it is assumed that these features may be discarded material from the nearby lime kilns.

In SB96:06, at $2.3 \mathrm{~m}$ depth near the base of the back hoe excavation, we encountered a thin, brown, sandy-clay layer which contained damp, rotted sandstone, some charcoal smears and cut pieces of cattle bone (identified by Ian Smith, a specialist in mammal bone). This find indicates that the overlying calcareous sands, and the layer of brown sandyclay, are of historical age and have been blown and pushed over levels at which there was discard of European rubbish.

It is difficult to interpret the Slaughter Bay sedimentary sequence and determine the level or levels within it at which prehistoric remains could occur. At the sea wall in the extreme eastern corner of the beach, fish and bird bone 


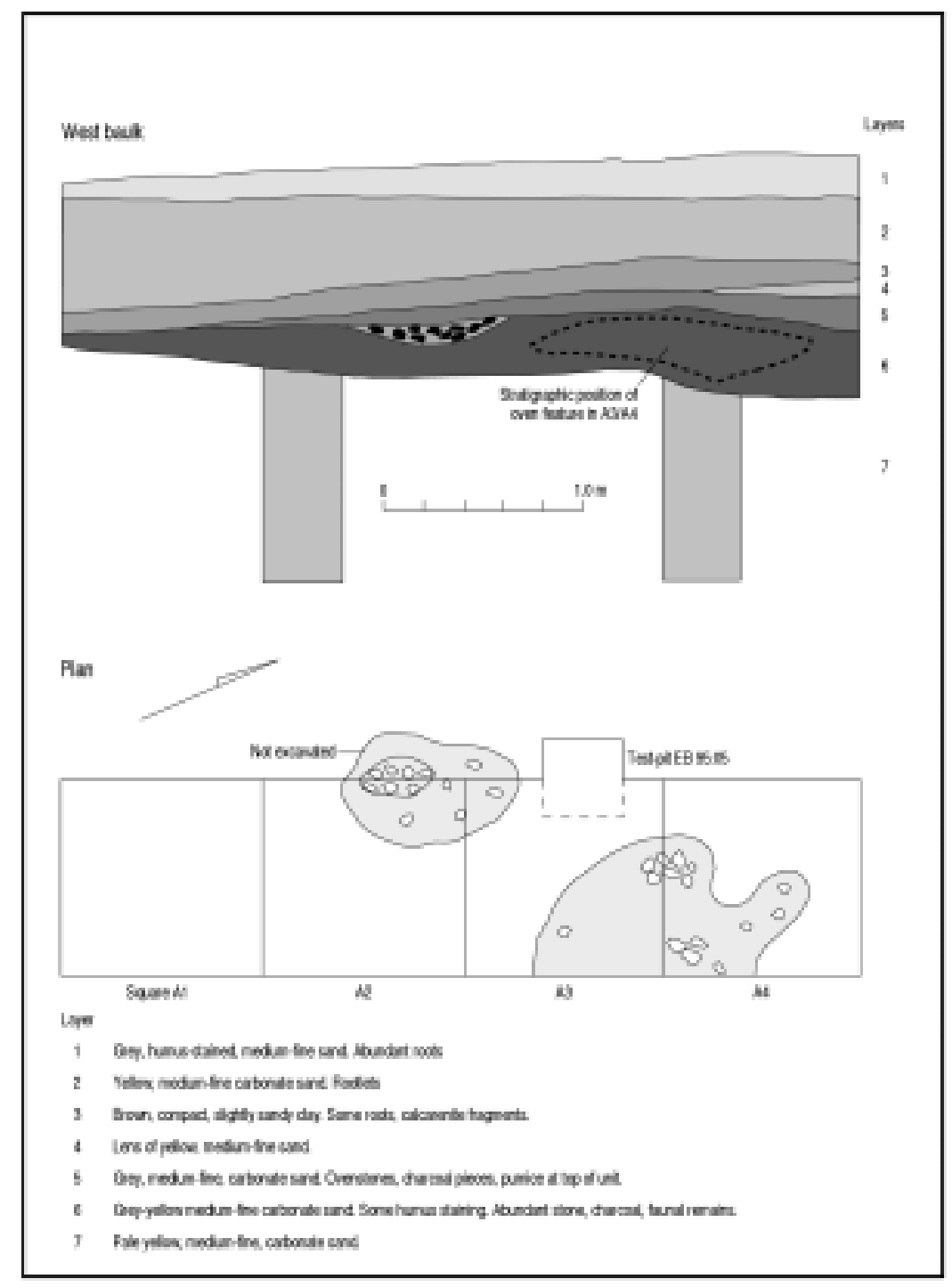

Figure 9. Stratigraphy and plan of Trench EB95:06.

together with an adze were recovered by Bevan Nicolai (above). There is no further sign of occupational debris there, and it seems that what remained was probably destroyed by the recent construction of the sea wall.

Where any depth of deposit is encountered in the eastern end of Slaughter Bay, the common sequence is: modern turf, calcareous sand (usually yellow, but also buff or containing humus-stained lenses), a layer of brown, sandy or silty clay which is compact and tough to penetrate, going down on to yellow calcareous sand beneath. The possible indication of prehistoric remains in SB96:03 occurred at the top of the last unit.

Since these sands would be highly mobile when exposed, it is quite possible that they were blown inland during the European era over the margins of the swamp, into which some butchery remains had been discarded previously (SB96:06). However, the brown clay is not mobile and it is difficult to see what could have shifted it over the dunes between the road and the swamp other than labour or machine. It is known that substantial dumps of "fill" (mostly clay and stone) were deposited and spread immediately to the west of the clump of pines in recent times and it seems very likely that this practice also occurred further east. If that was the case, then the stratigraphy above the yellow medium sand and rock is all comparatively recent and no prehistoric material will be encountered within it, at any rate in situ.

While these initial investigations suggest that prehistoric remains are not abundant in eastern Slaughter Bay-and the absence of charcoal-stained layers is particularly indicative of low density or absence-it will still be necessary to continue looking. Several test trenches closer to the base of the calcarenite massif, and further augering in the central and western parts of the bay may be warranted. There is, however, nothing to show that the Emily Bay site continued into Slaughter Bay. The area between has been heavily disturbed by public works over the last two centuries which might have destroyed some of the evidence, but the stratigraphy on the western side of the Emily Bay site indicates that it did not reach the present drainage ditch. Consequently, it seems almost certain there was a preEuropean settlement site in Slaughter Bay, the erosion of which has left numerous adzes and basalt flakes along the eastern part of the beach. 


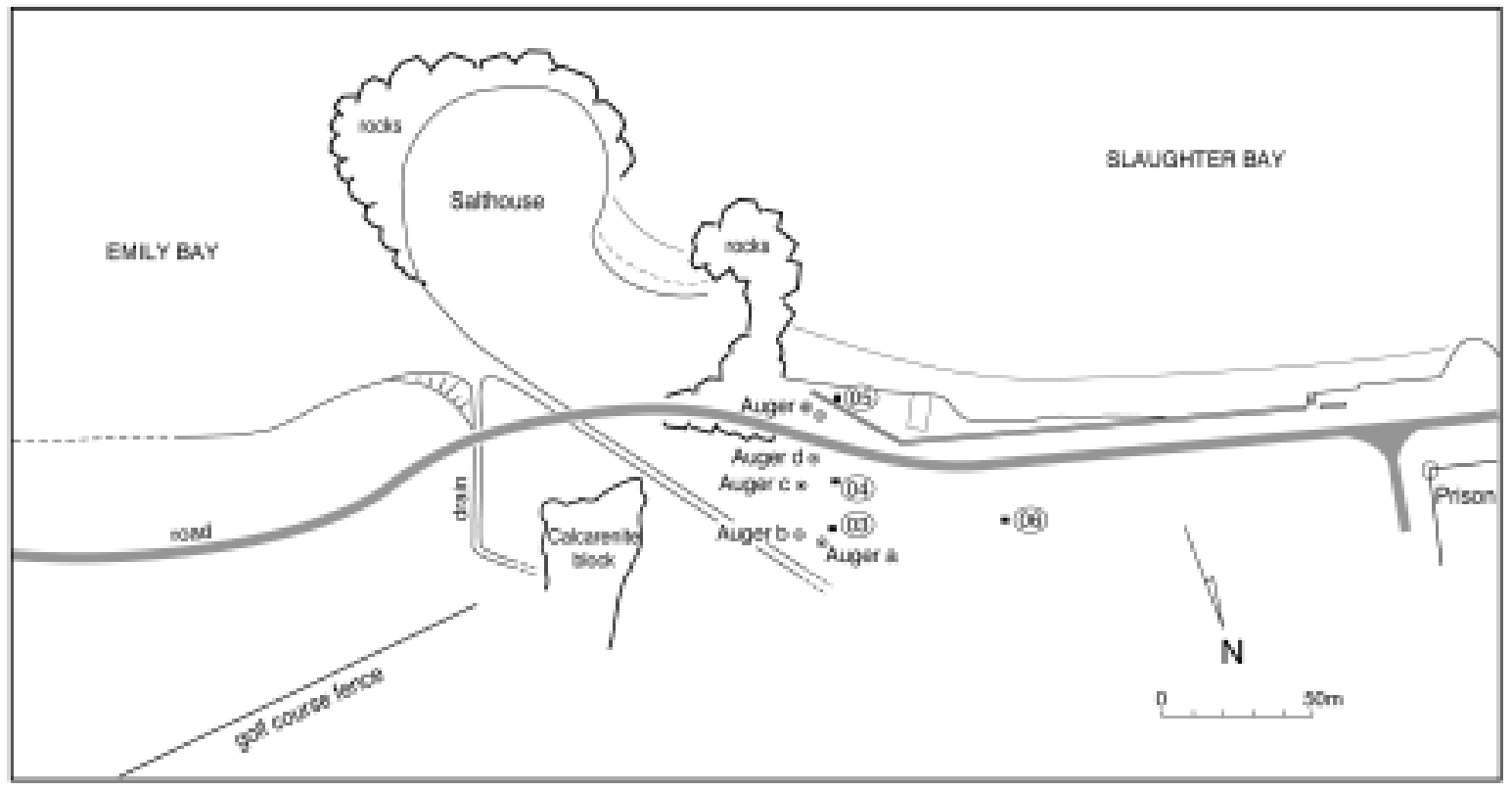

Figure 10. Auger holes and trenches in Slaughter Bay. SB96:03 incorporates SB96:01 and SB96:05 incorporates SB96:02.

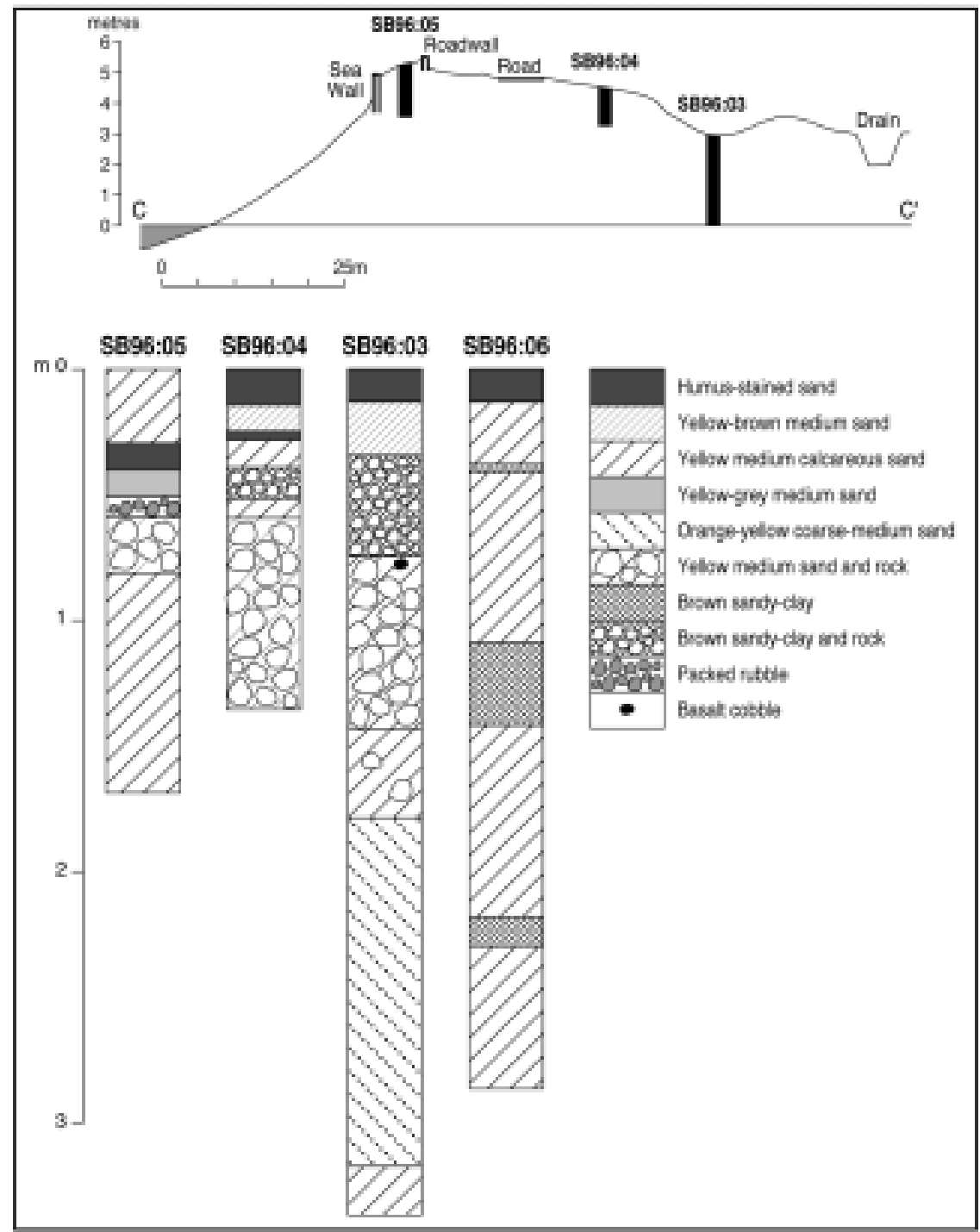

Figure 11. Stratigraphy of trenches in Slaughter Bay. 


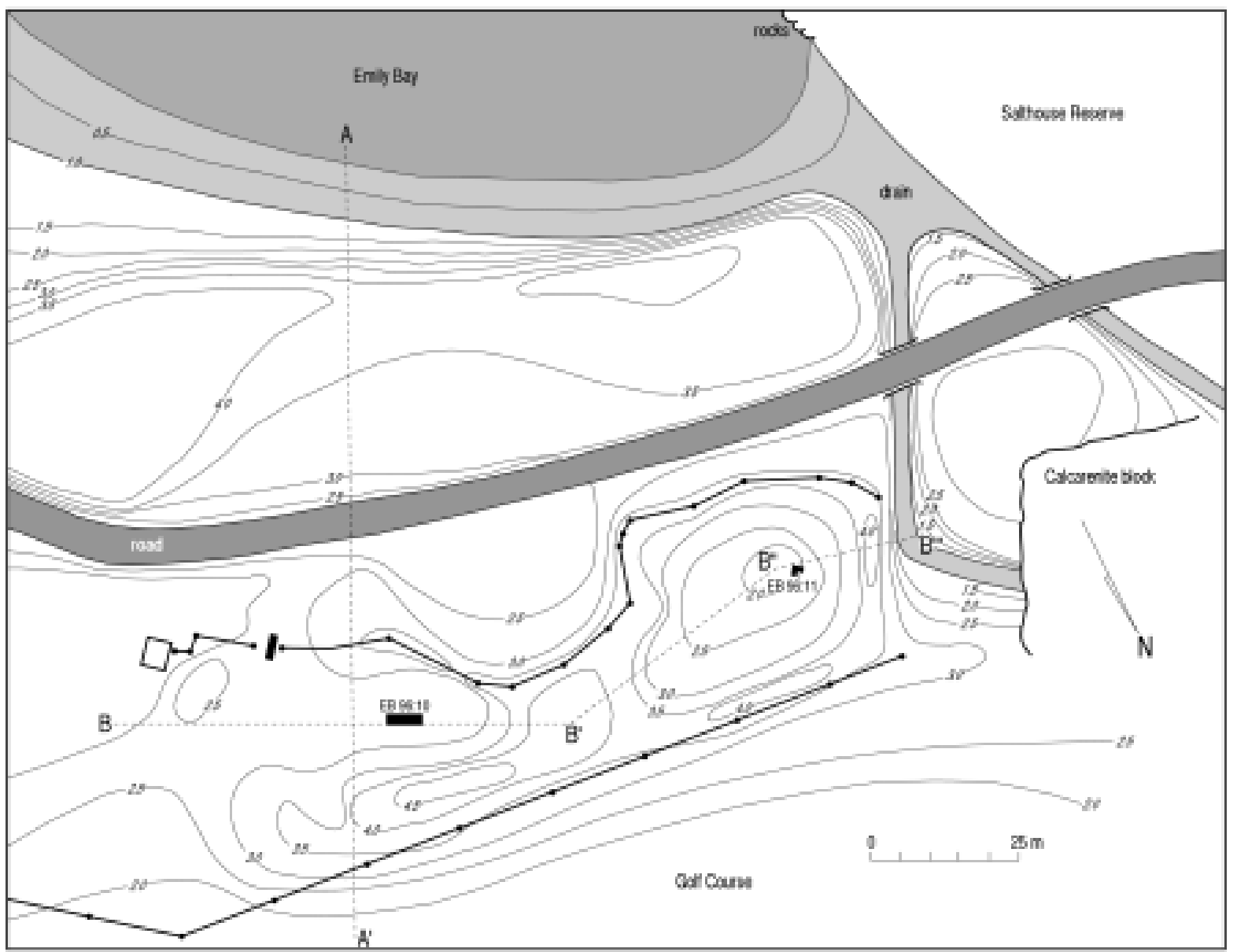

Figure 12. Location of trenches at Emily Bay in 1996, showing transect lines for stratigraphic analysis (Figs. 14, 15).

Emily Bay. The tasks at Emily Bay were to continue defining the extent of the site-areally and stratigraphically - and to expand the very small sample of it which was exposed in December 1995. The site was mapped and a contour plan drawn of the present land surface. Excavations were undertaken in each of the two main swales in which the site occurs (Fig. 12).

Extent of site. Thirty-six auger holes were drilled in order to define the boundaries of the site and its main stratigraphic pattern (Fig. 13). The details of each hole were recorded and then selected holes used to draw the stratigraphy along two axes of the site (Figs. 14, 15). As can be seen from these, the site is laid on a level to slightly undulating surface, but there are more substantial dunes deposited above it. These comprise a sinuous line along which runs the seaward fence of the pine plantation, and a second line inside the golf course fence. There are cross-dunes at the drain and through the centre of the site area. The effect of these is to create two large swales in which the archaeological remains are more accessible than elsewhere. It is in these swales that excavations have occurred: in the large eastern swale and its run-out area in December (Trenches EB95:05, EB95:06) and April (EB96:10), and in the smaller western swale in December (EB95:04) and April (EB96:11).

The auger holes showed that the site extends north-south for approximately the width of the plantation. It is possible that this coincidence results from protection of remains under the dunes, while former parts of the site were deflated or destroyed by earthmoving. However, the stratigraphy, indicating a thinning of the cultural layer at each extremity, suggests that the current site boundaries might define the original extent along this axis. Along the east-west axis, there appear to be gaps in the distribution. The main part of the site lies under the eastern swale, but does not extend further east than the sand road. The prehistoric cultural layer thins towards the central cross-dune and does not appear immediately on the western side of it. In the western swale, there is a discontinuous distribution of cultural stratigraphy.

Trench EB96:10. Auger holes showed that in this area the stratigraphy was very similar to that encountered in EB95:05 and EB95:06, but that the cultural layer was blacker in colour, indicating a cooking area, or possibly domestic hearths. The backhoe was used to scrape the overlying sand off an area $6.3 \times 1.7 \mathrm{~m}$, down to the brown clay. This was then chipped off by hand and an excavation area of $6.0 \times 1.5 \mathrm{~m}$ was set out (Fig. 16).

Excavation disclosed a single cultural layer, varying in thickness from $0.15 \mathrm{~m}$ to $0.40 \mathrm{~m}$ (Fig. 17). It was directly overlain by the brown clay and underlain by medium-fine, yellow calcareous sand. The cultural layer was excavated in $0.10 \mathrm{~m}$ spits. It appeared as a compact grey-brown sand, grading to dark grey and black at the eastern end of the excavation. In that area, were numerous ovenstones and the pits of three scoop ovens, one apparent in spit 1 and the others in spit 2. Other possible structural features were investigated in spits $2-3$. Several appeared, initially, to be post-holes, but all proved upon further excavation to be the remains of root holes. In spit 2, extending into spit 3, at the 


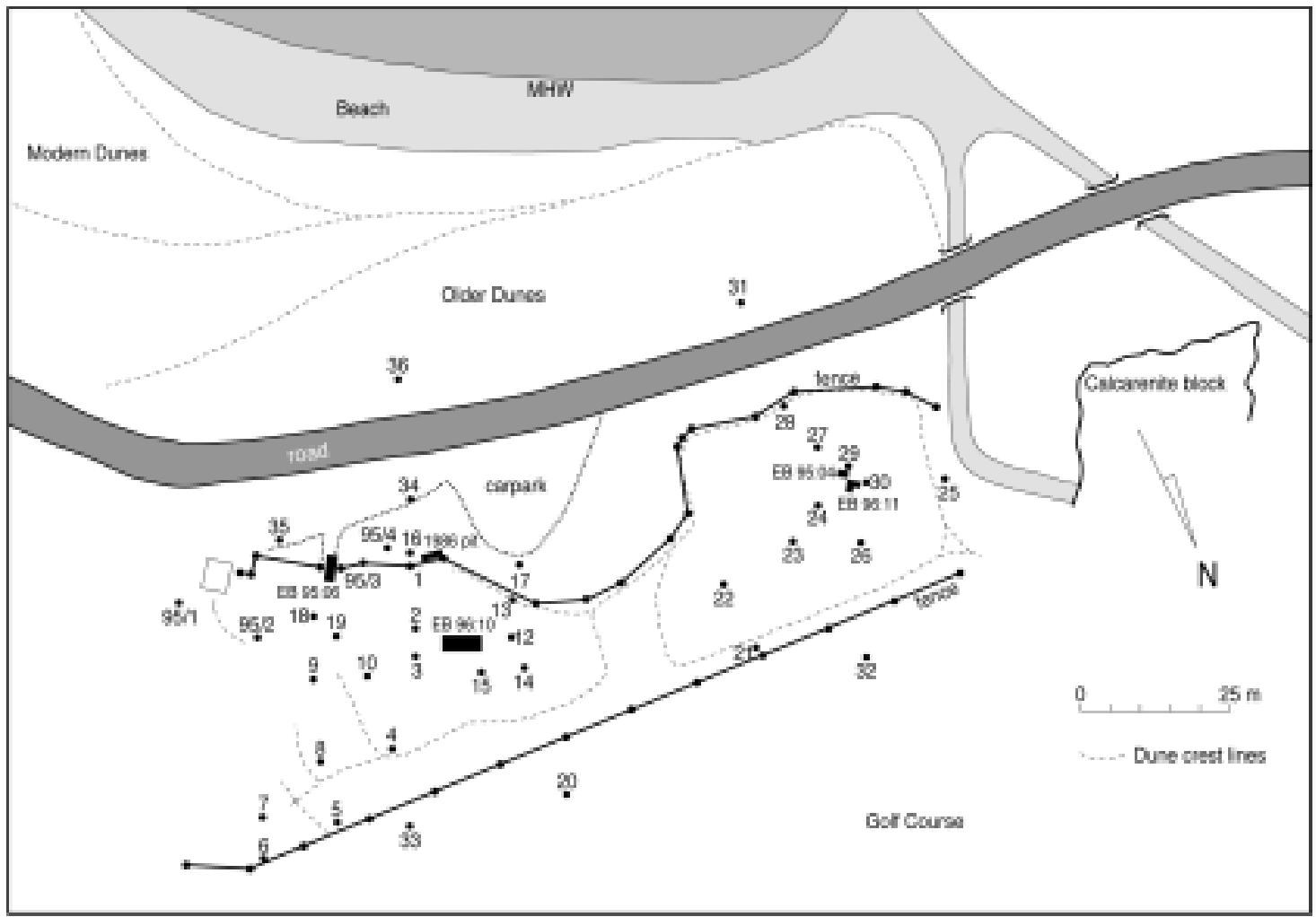

Figure 13. Location of auger holes excavated in 1996 at Emily Bay.

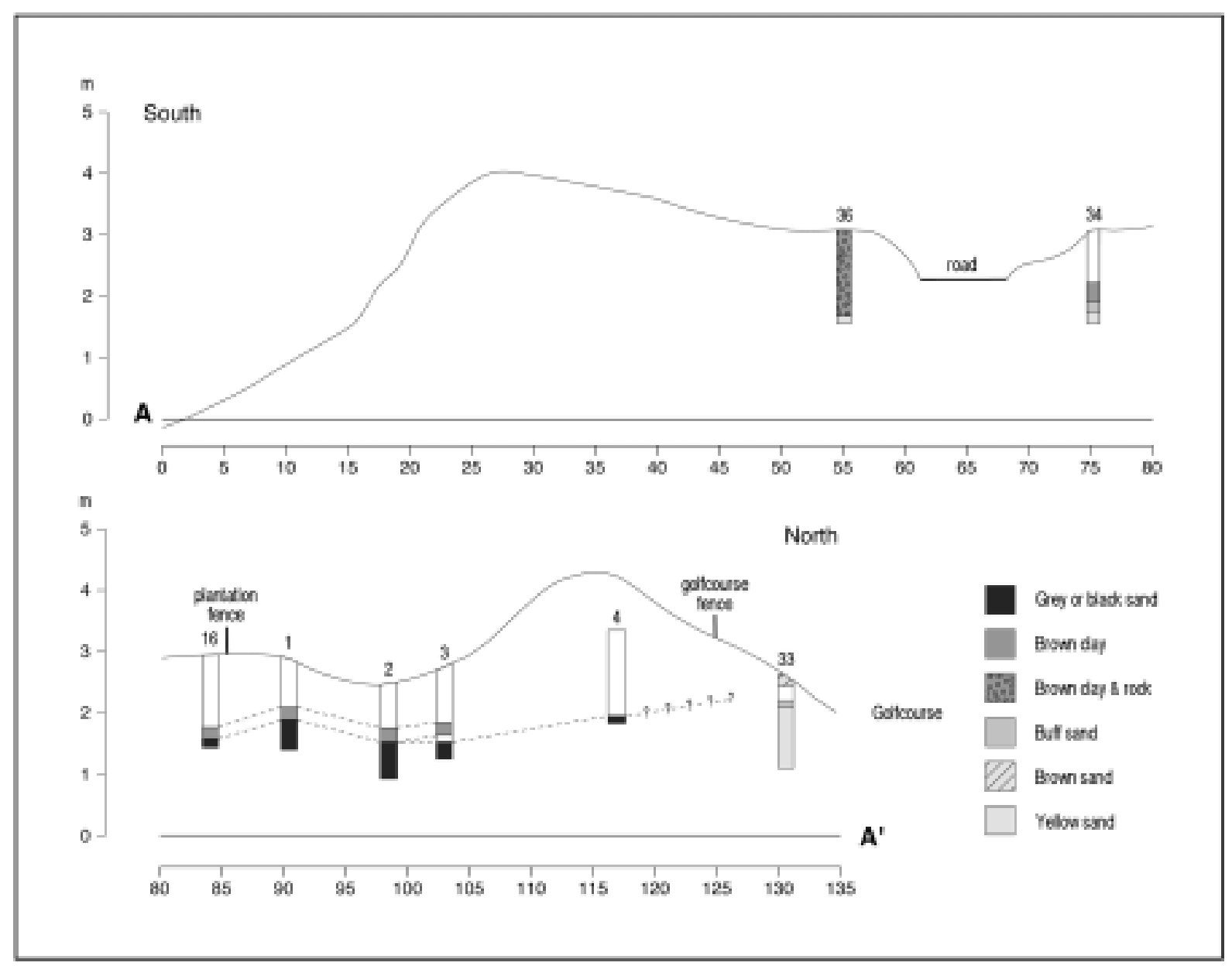

Figure 14. Stratigraphy in A transect at Emily Bay. 


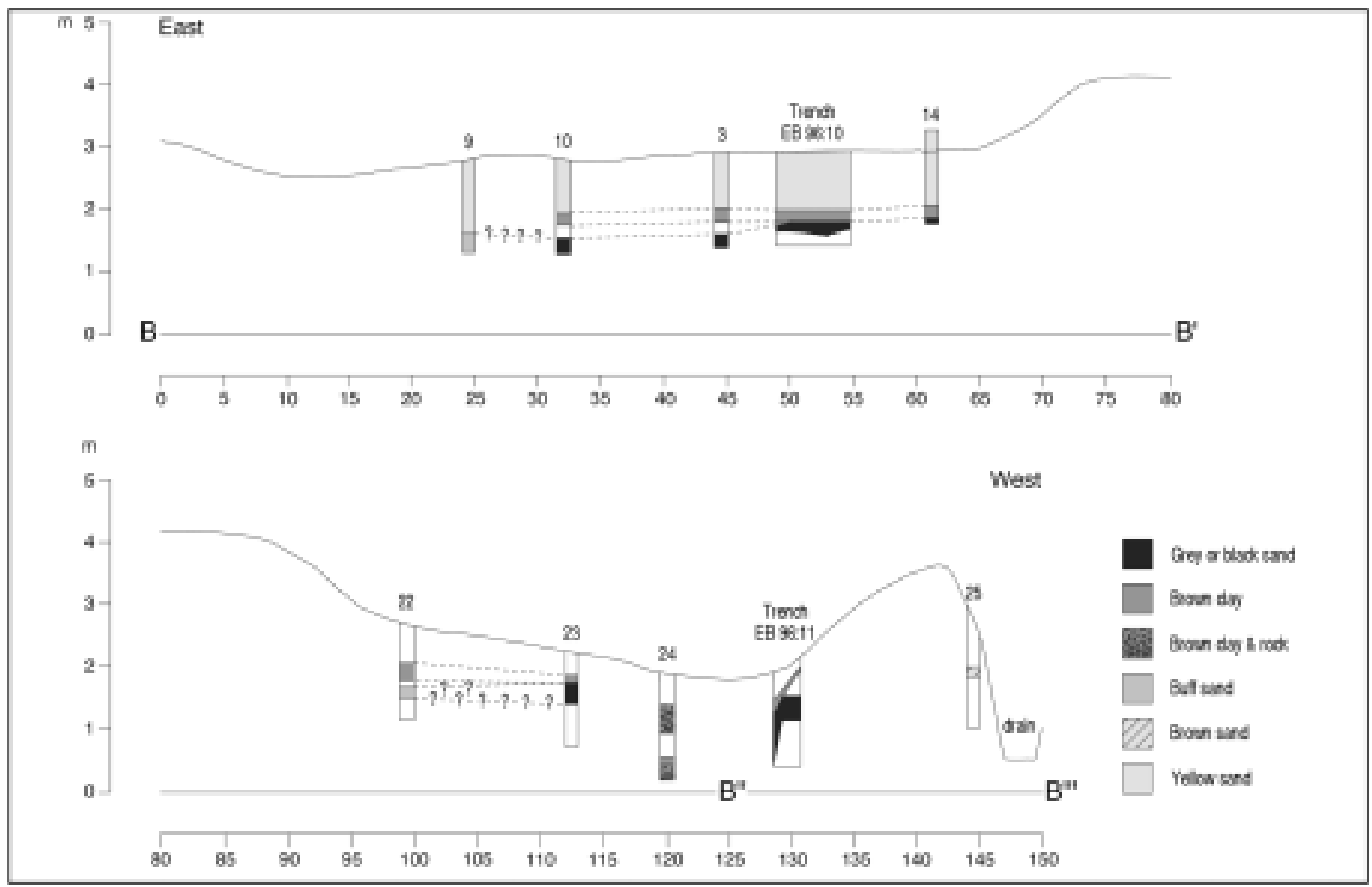

Figure 15. Stratigraphy in B transect at Emily Bay.

western end of the excavation was a rubbish pit, filled with fish and bird bone (Fig. 18). Midden remains were otherwise less abundant than in Trench EB95:06, but there were some different materials, including turtle bone (most of a scapula in one place) and the worked pieces of a large pelecypod. Basalt flakes from adze manufacture were fairly common, but no other lithics were discovered. In this excavation and also in EB96:11, all material was sieved through $4 \mathrm{~mm}$ mesh and the residue retained for laboratory analysis.

Trench EB96:11. A $3 \mathrm{~m}^{2}$ excavation was opened in the western swale. The undamaged stratigraphy proved to be much as it is elsewhere in the site, with a cultural layer evidenced by $0.4 \mathrm{~m}$ of black sand grading down to $0.3 \mathrm{~m}$ of grey sand (at a total of $0.7 \mathrm{~m}$, the thickest part of the cultural layer in the site), overlain by a brown clay-separated from it by some yellow sand in places-and underlain by yellow sand (Fig. 19).

In the eastern part of the excavation, the even deposition of layers terminates in ragged, slumped lenses. Some agency has cut away the site and left a steep edge, down which lenses of the various stratigraphic units-black sand, grey sand, yellow sand and brown clay-have tumbled and interleaved (Fig. 19). The damage extends through the area of Trench EB95:04. Further east, in the centre of the western swale, there is no evidence of the site, and it can be assumed that the same event or events were responsible for removal of it. The most probable explanation is that we have uncovered the edge of a cutting through which ran a road. The auger hole (Fig. 15, Auger hole 24) which was then expanded into a small pit in the centre of the swale disclosed two levels of hard-packed brown clay and rock which could only be penetrated with a crowbar. These are probably surfaces of a road in this area (apparently of Second Settlement age) which began at the junction of Bligh Street

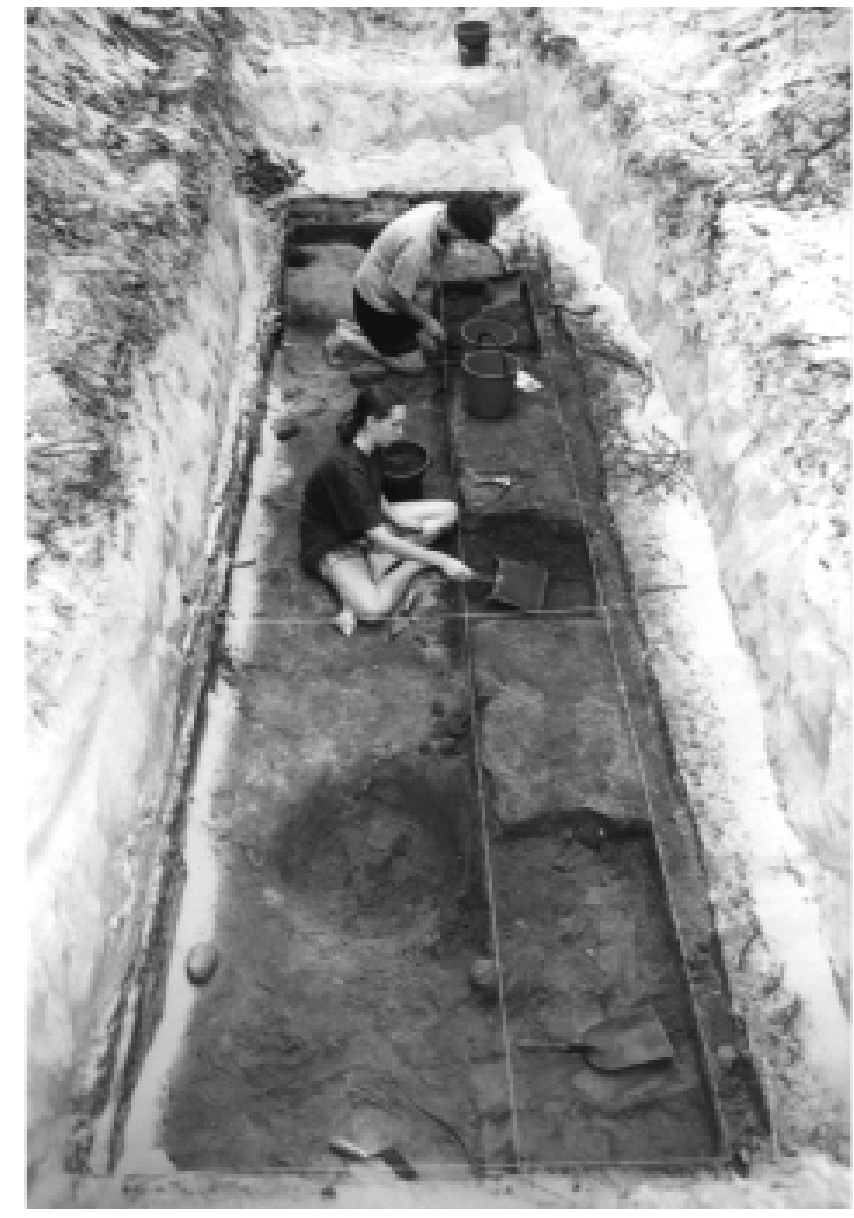

Figure 16. Excavation of Trench EB96:10, showing hearth pits. Kirsten Anderson and Rosanne Anderson excavating. 


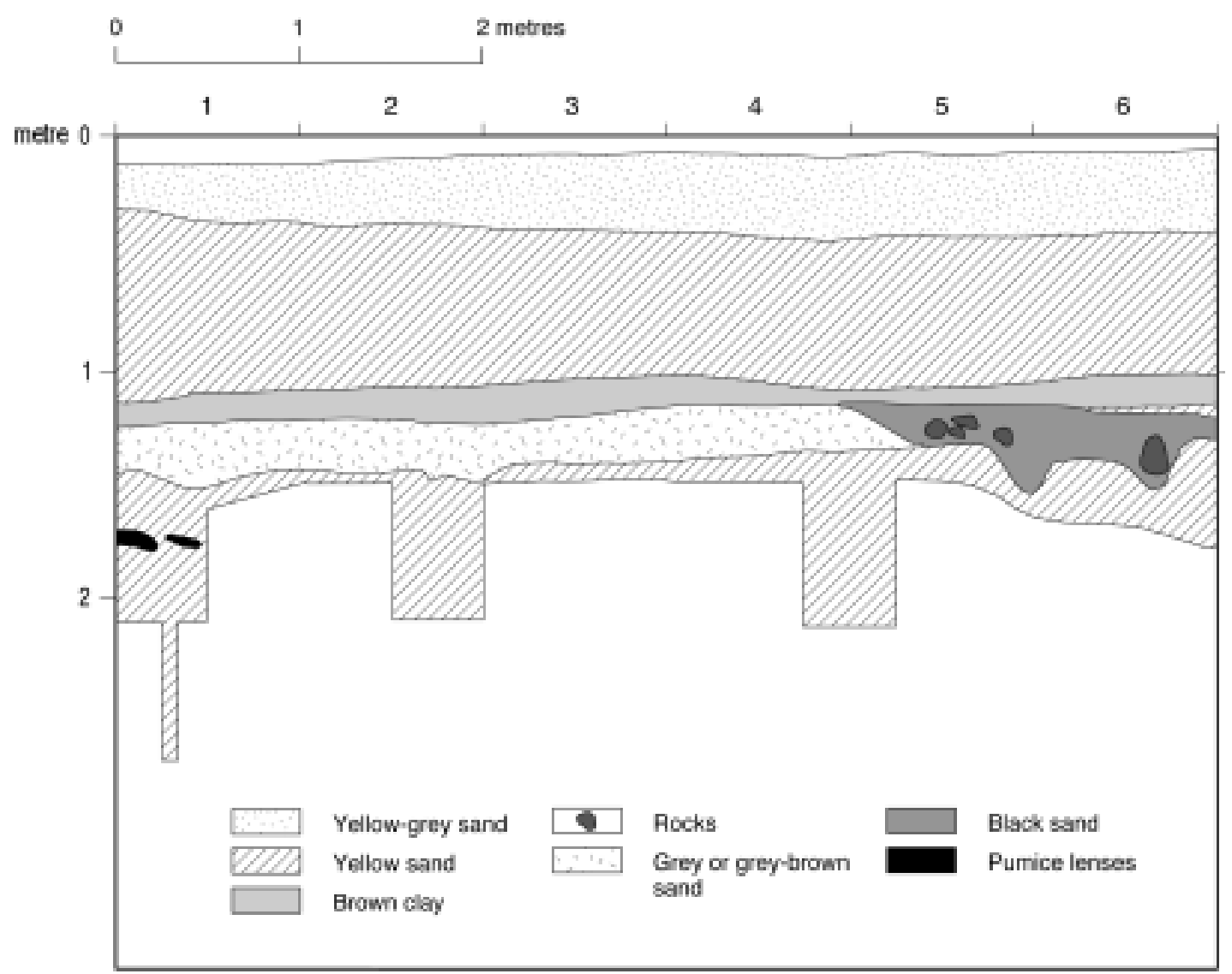

Figure 17. Stratigraphy of northern baulk of Trench EB96:10.

\section{Cultural Layer, Spit 1}

(1)

(2)

(3)

(4)

(5)

(6)

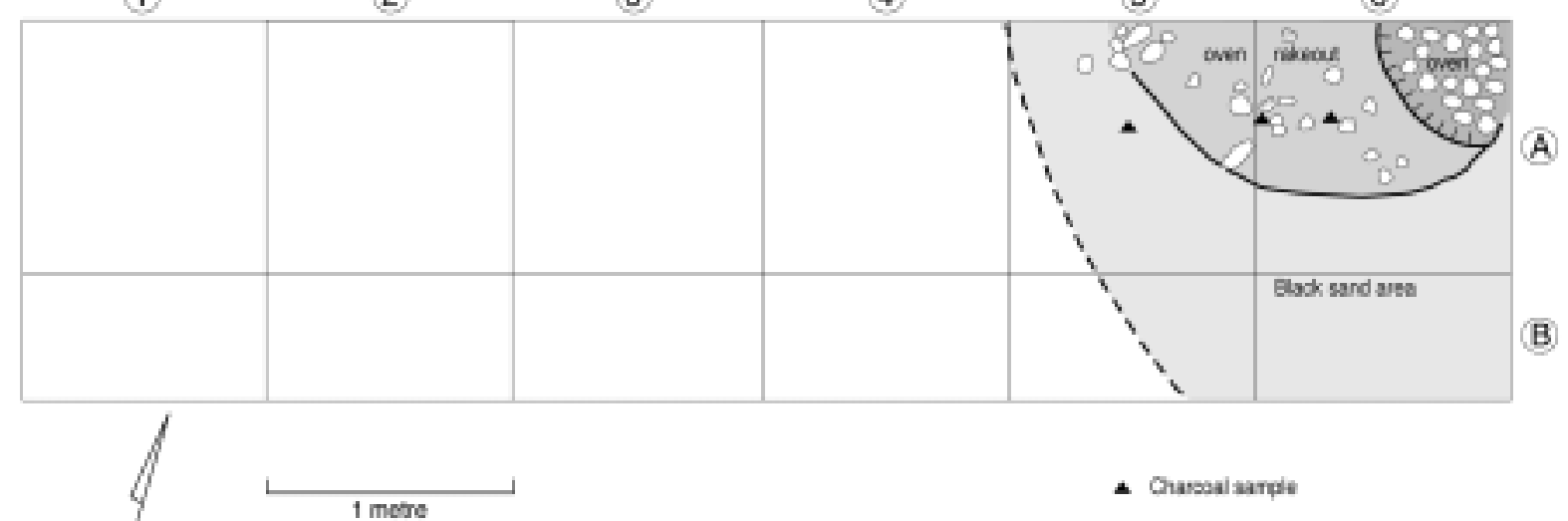

Cultural Layer, Spit 2

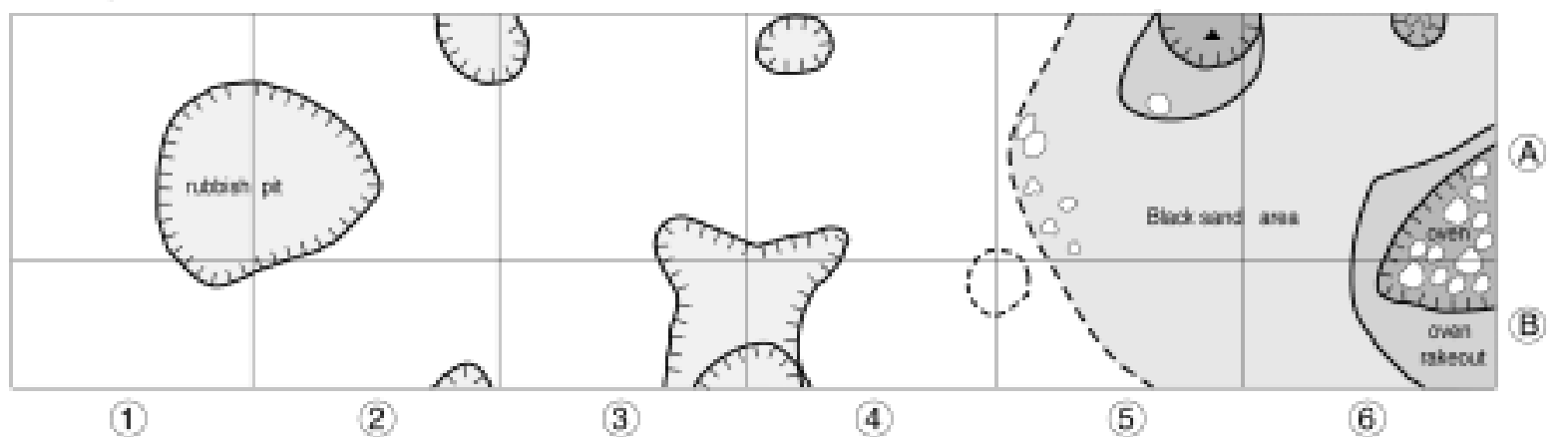

Figure 18. Plan of Trench EB96:10. 

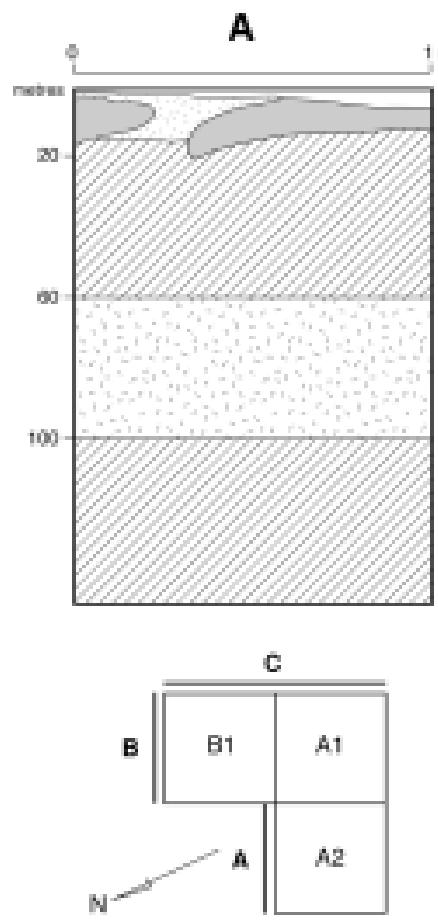

B
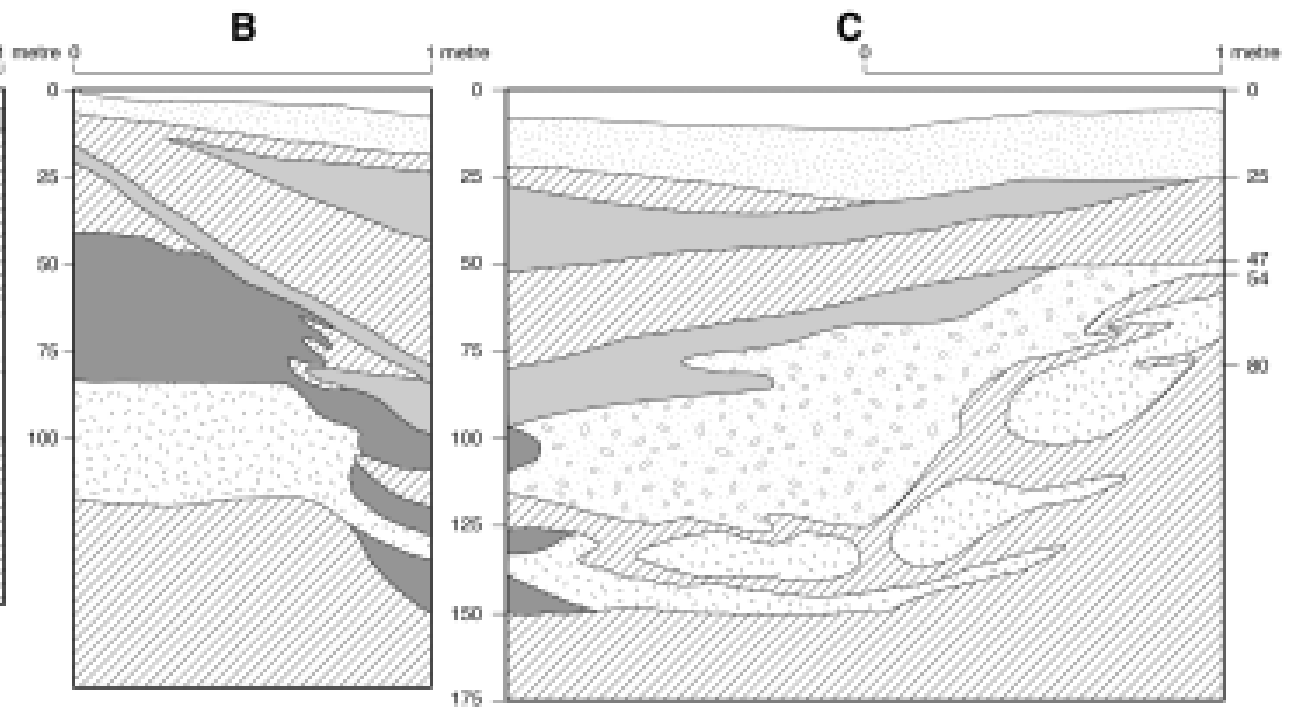

Yolow-grey sand

Yelow sand

Erown cloy

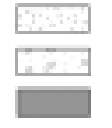

Grey or grey-brown asnd Yelow sand whi brown sol motbes

Baok sand

Figure 19. Stratigraphy of Trench EB96:11.

and Bay Street, ran across the drain, curved through the area of the western swale and terminated in a limestone quarry east of Government House.

The material recovered from this excavation was rather different from that obtained in the trenches in the eastern swale. A broken head of a rotating harpoon made from turtle bone and a blade of obsidian were found. There were numerous basalt flakes, some of which had come from polished adzes, a large, unifacially-retouched basalt blade and the butt of a trilaterally-flaked adze preform. This material looks like the debris that might be expected in a domestic area, compared to that which was recovered in the eastern area. Midden remains mainly comprised fish bone, with much less bird bone than was apparent in earlier excavations. A burnt and broken dog carnassial tooth was recovered and also a shark tooth.

These discoveries, including the evidence of greater diversity than previously documented in the archaeological materials, and most particularly the obsidian blade with its promise of sourcing the origin of the prehistoric settlers, encouraged planning for a third field season.

\section{Fieldwork in 1997}

Emily Bay. The nature of the evidence in 1996 indicated that a substantial open-area excavation in the western swale would repay the effort. The area had to be selected quite carefully because an original request to the Australian Heritage Commission for permission to excavate up to 150 $\mathrm{m}^{2}$ was negotiated down to a total excavation area of 45 $\mathrm{m}^{2}$, about $3 \%$ of the area of the swale. In the event, the discovery of stone paving required a special application from the field to KAVHA and the AHC for additional excavation area, resulting in permission for a further 10 $\mathrm{m}^{2}$. The 1997 excavation areas are shown in Fig. 20. All excavated material was sieved to at least 4 or $5 \mathrm{~mm}$ mesh size (it became necessary to borrow an older sieve with 5 $\mathrm{mm}$ mesh from the Norfolk Island Museum). Where small stone flakes or faunal remains occurred, the excavated material was washed through $2 \mathrm{~mm}$ sieves. The residue was bagged and later sundried and sorted into major components (shell, bone, stone, charcoal etc.), re-bagged and retained for laboratory analysis. Whole samples of approximately two litres each were also taken from each square, sundried, sieved to remove sand and re-bagged for laboratory analysis.

In planning the main areas to open up, the information of the 1996 auger holes and EB95:04 and EB96:11 excavations was supplemented by two test-pits (Fig. 21).

Trench EB97:21. An excavation of $1.5 \mathrm{~m}^{2}$, on the western slope of the swale, cut through yellow carbonate sand containing a sloping layer of brown clay mixed with sand and calcarenite, to reach the level surface of the cultural layer at $0.83 \mathrm{~m}$ (Fig. 22). This proved to be $20 \mathrm{~cm}$ thick, with one small, deeper depression in it. At $5 \mathrm{~cm}$ below its surface in square Z1 there was a fine example of a basalt adze preform, triangular in cross-section (Turner, Anderson and Fullagar, this vol.).

Trench EB97:22. A $1 \mathrm{~m}^{2}$ excavation on the eastern slope of the swale encountered a similar stratigraphy to EB97:21, with the surface of the cultural layer reached at $0.7 \mathrm{~m}$ depth. In it, at $5-10 \mathrm{~cm}$, there was a number of calcarenite slabs, laid flat, and in the northeast corner, at $10 \mathrm{~cm}$ depth, a small group of upright stones set above a hammerstone (Anderson and Green, this vol.). Burnt, broken cobbles were found in the southern part of the square. In due course, this excavation became incorporated into EB97:24 as square Z5.

Trenches EB97:23, EB97:24. These were the major excavations at Emily Bay. As such they constitute the subject of most of the chapters in this volume, and are described only briefly here. Both excavations were situated in the western swale, although the topography was different at the time of site occupancy. It is apparent that the Emily 


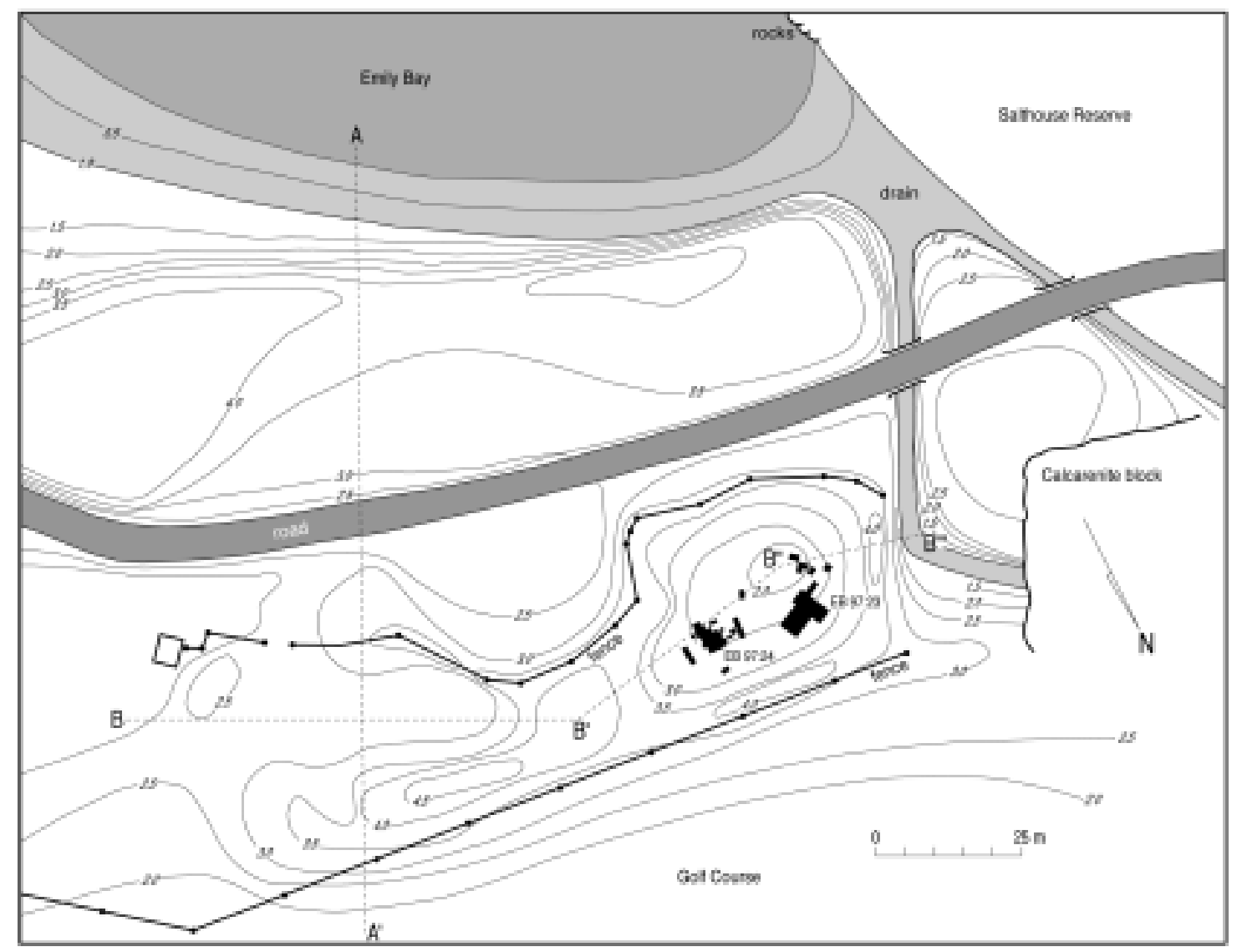

Figure 20. Location of trenches at Emily Bay in 1997.

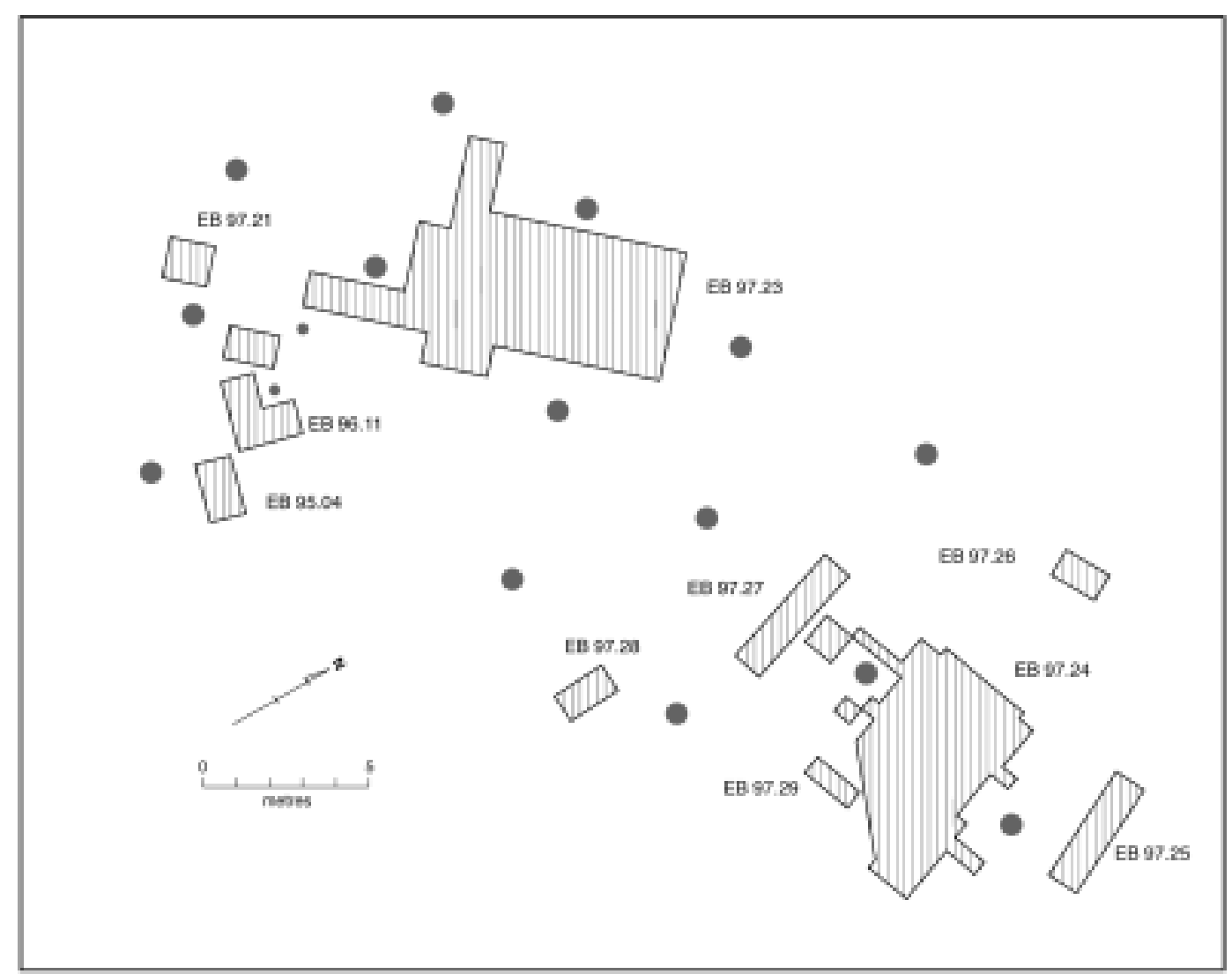

Figure 21. Plan of excavated and cleared areas at Emily Bay, 1997-shaded circles indicate tree boles. Note that EB97:23 includes adjacent unlabelled small trench to the south. 


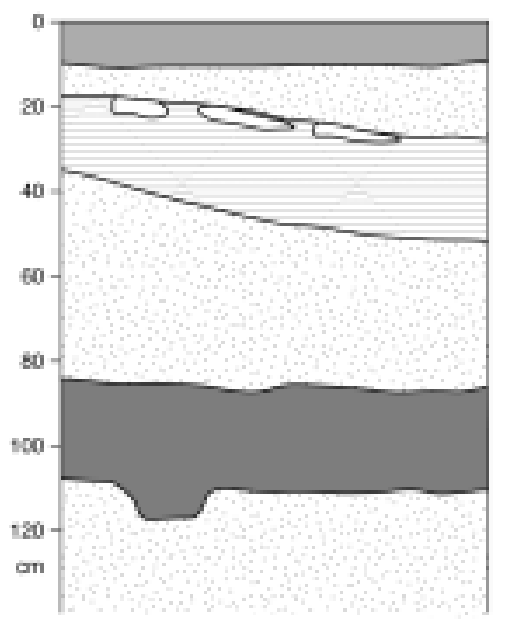

Greybrown sand

Bupw day mixed with sand and leness of yeliow sand

Wedum-fne yelow send

Cutural isyer of grey-dsck sand

Figure 22. Stratigraphy of northern baulk of Trench EB97:21.

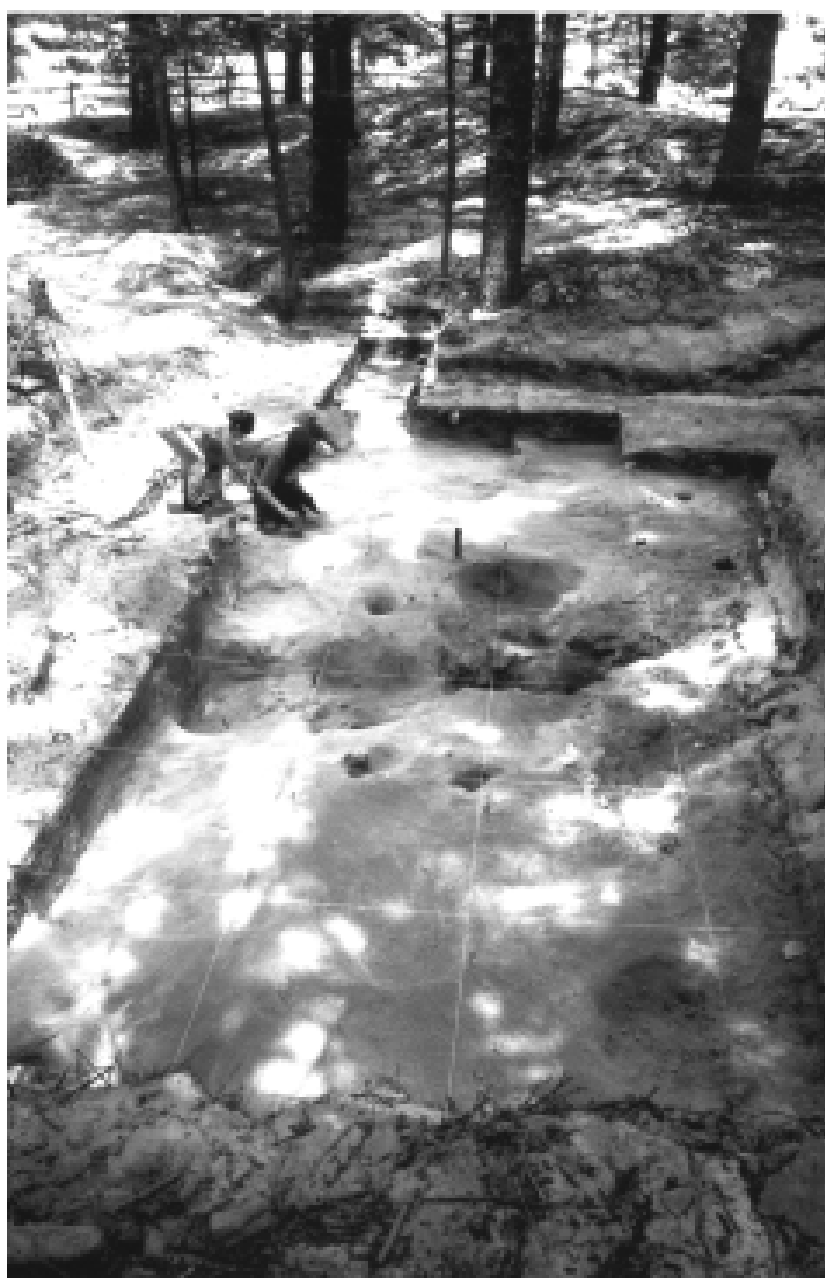

Figure 23. Excavation of EB97:23, seen from north. Note the heavily disturbed central squares of the excavation inside the postholes. Penny Crook and John Anderson excavating.
Bay site in general was located initially upon a surface which, while not flat, did not have the topography of the modern dunes. There is carbonate sand for 0.7-1.2 m under the cultural layer in the eastern swale, but beneath it in the western swale is mixed sand and water-rolled gravel and cobbles; material which has the appearance of a former beach or wind deflation area. It is possible that there were no active dunes in Emily Bay at the time of initial preEuropean colonization and that the settlement was placed upon a more or less flat surface situated about $1.0 \mathrm{~m}$ above the high tide level (our survey indicated that the base of the cultural layer, where it was undisturbed, was about $1.3 \mathrm{~m}$ above high tide level in the eastern swale and $1.0 \mathrm{~m}$ above in the western swale).

On the basis of the test-pits, a $39 \mathrm{~m}^{2}$ excavation (Figs. $23,24)$ was undertaken in the northwest quadrant of the swale (EB97:23). The stratigraphy is generally straightforward. Under the pine duff is a layer of pale yellow carbonate sand of varying thickness and, running through it, following a former dune surface, is a thin $(8-15 \mathrm{~cm})$ band of brown soil, a fairly recent palaeosol. Beneath is a thick layer $(0.6-1.0 \mathrm{~m})$ of the same pale yellow sand which, over most of the excavation, covers the almost level surface of the cultural layer, observed as a grey-brown sand with black patches in it. In squares A-B 6-8, and E-F 6-8, lenses of stiff brown clay lay directly upon the cultural layer (below).

The cultural layer in EB97:23 is generally about $0.3 \mathrm{~m}$ thick and grey-brown in colour, and we excavated about $11.7 \mathrm{~m}^{3}$ of it. Except in small patches, mostly near the postholes, and within and around the large oven in A-B 7, charcoal is scarce. Similarly, there was very little shell midden, and it consisted only of small patches of Nerita sp. (Campbell and Schmidt, this vol.). Bird bone was much more common. Most of it is broken, and some burnt, which is characteristic of midden, but some will also be from mutton birds which died naturally on the site (Holdaway and Anderson, this vol.). Fish remains (Walter and Anderson, this vol.) were sparsely scattered, and there were several pieces of turtle and mammal bone (Smith, Clark and White, this vol.). Basalt flakes were distributed about the site, in no apparent pattern and one flake of translucent obsidian was recovered from square E12, spit 4 (Turner, Anderson and Fullagar, this vol.).

The excavation of Trench EB97:22 had located some flat slabs which appeared to be paving. Additional excavation in this area (Fig. 25) uncovered a paving structure, discussed by Anderson and Green (this vol.). Nineteen square metres of this were excavated as Trench EB97:24. This part of the site was covered by up to $0.6 \mathrm{~m}$ of medium-fine yellow carbonate sand above a 10-15 cm thick layer of brown clay enriched with sand and fragments of calcarenite. Beneath was $5-10 \mathrm{~cm}$ of yellow carbonate sand overlying the cultural layer (Fig. 26). The latter, 15$25 \mathrm{~cm}$ thick, with slabs embedded within it, lay upon coarse brown sand containing abundant water-rolled gravel, which also occurred in the interstices between the paving. The brown clay layer dips steeply along the southwest edge of the paving to flatten out at about $1.2 \mathrm{~m}$ below the paving level, indicating that the loss of a paving edge along that side occurred prior to the formation of the brown clay, although the latter is almost certainly a European feature (see later).

It was not possible to excavate out to the limits of paving 


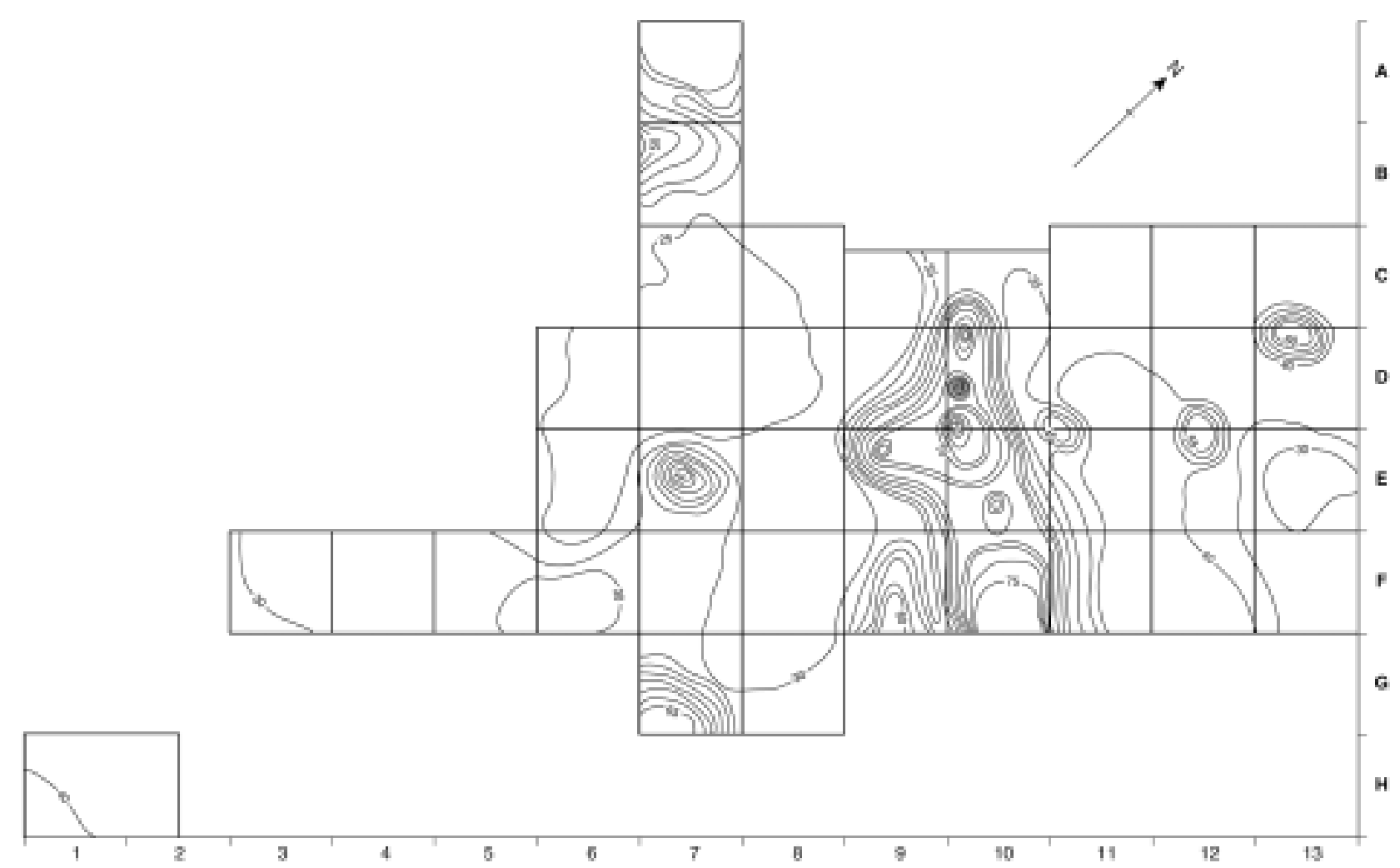

Figure 24. Contour plan of the depth of the cultural layer in Trench EB97:23.

stones along the west side, because of restrictions on permitted excavation area, and it would have been desirable to excavate further to the east as well. However, extensive probing in these areas, and a series of trenches (EB97:25, $26,27,28,29)$ cleared down to the surface of the cultural layer, which was not excavated, showed that the exposed paving constituted the full feature, as it presently survives. The paved area is discussed at length by Anderson and Green (this vol.). These trenches also indicated that the disturbed deposit at the southwest edge of EB97:24 continued through the southern half of EB97:27 and that EB97:28 exhibited brown, rubble-filled clay in the northern half of the square, perhaps a further indication of the historical roadworking which runs through the centre of the western swale. Mention of that feature raises the more general question of the degree to which the Emily Bay site has been exposed to postdepositional disturbances of any kind.

Site Taphonomy. The Emily Bay site appeared initially to have been protected from post-depositional disturbance in the areas excavated in 1995 and 1996 in the eastern swale area by the tough brown clay layer over it. However, this layer is discontinuous at best in the western swale and there is evidence of at least four agencies of site disturbance there. First, within the historical era a roadway had been constructed through the centre of the western swale, and that seems to be evidenced in several auger holes. Further signs of historical disturbance reaching to the prehistoric cultural layer are evident in Trench EB97:23, squares A-B, 6-8 (the 6 and 8 rows in A-B were cleaned down to the top of the cultural horizon but only row 7 was excavated). A large oven feature containing many basalt cobbles was situated within the cultural layer and, almost immediately above it like a mirror image, was a low mound of calcarenite slabs (Fig. 27). The mound was sitting upon a thin layer of stiff brown clay packed with clasts of basalt and calcarenite which, in turn, lay directly upon the surface of the cultural layer. A piece of European china in the brown clay indicates that it, and the mound, are of European age, so the situation of these features together can only be coincidental.

Second, either as a result of a road cutting, or by natural agencies, the site is badly slumped along the eastern edge of excavation EB96:11. That at least some of this is probably natural (wave damage is suspected), is indicated by similar ragged slumping of the edge of the site in a curved "bite" along the SW edge of excavation EB97:24 which had caused that edge of the paved feature to collapse. Since the site is quite close to high tide level (below), and was probably closer to the shore before the formation of the modern dunes south of the road, it was vulnerable to storm damage. In both Emily and Slaughter Bay, in fact, there is a history of wave erosion which has uncovered burials and washed out numerous adzes, basalt flakes and other material (Specht, 1984). The current seaward boundary of the site is therefore probably an artefact of natural processes.

Third, in a process which is continuing today in the western swale, muttonbird burrowing into and through the cultural layer is redistributing material from above the archaeological horizon, into and below it. There is some evidence of this in the distribution of landsnails (Neuweger, White and Ponder, this vol.). The burrowing, which is most apparent as a deep disturbance across the centre of the EB97:23 excavation (Figs. 24, 28), has carried material to $0.9 \mathrm{~m}$ below the cultural surface. 


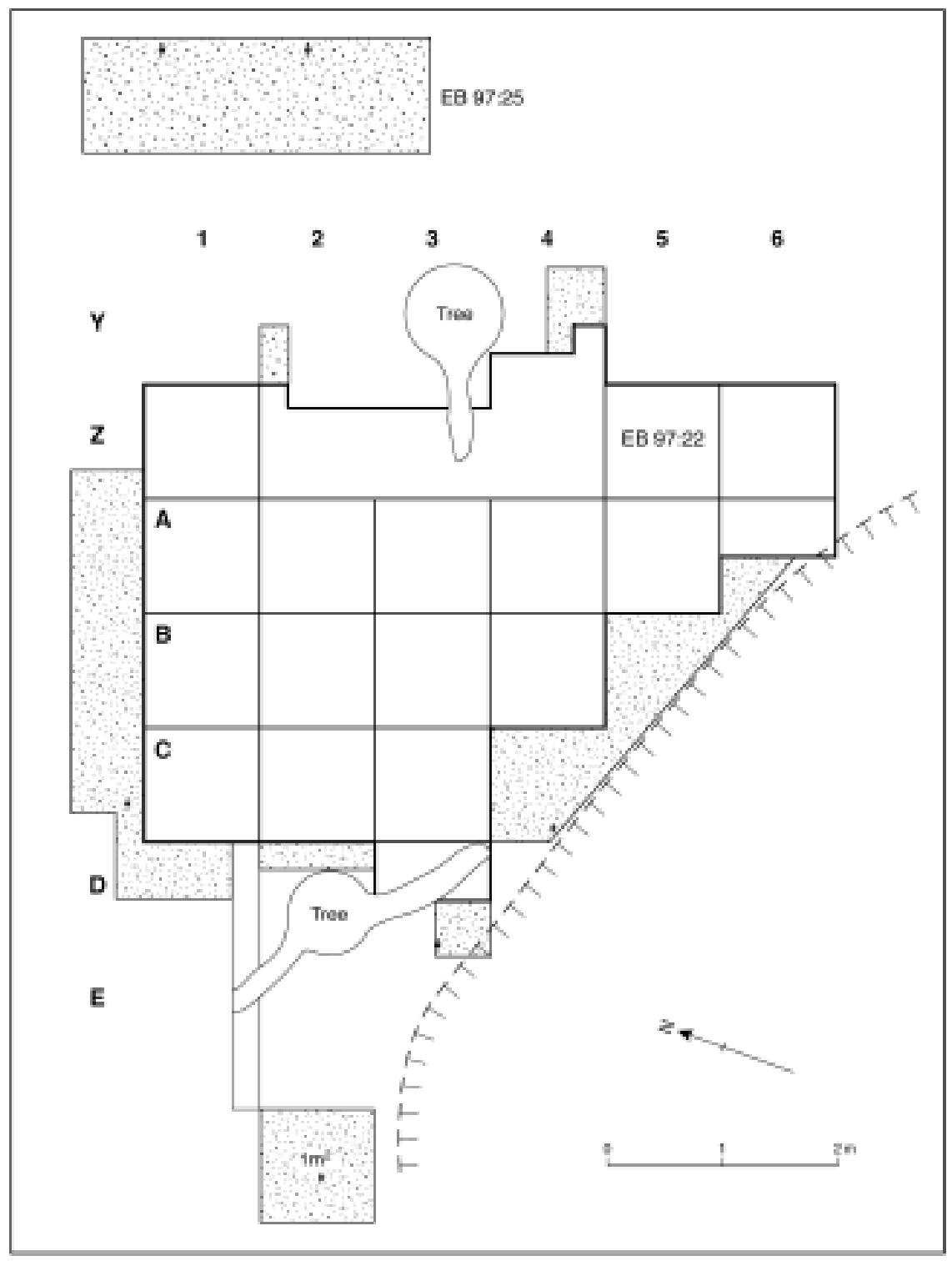

Figure 25. Plan of the excavated area of Trench EB97:24. Stippled areas were cleared of sand but the cultural layer was not excavated.

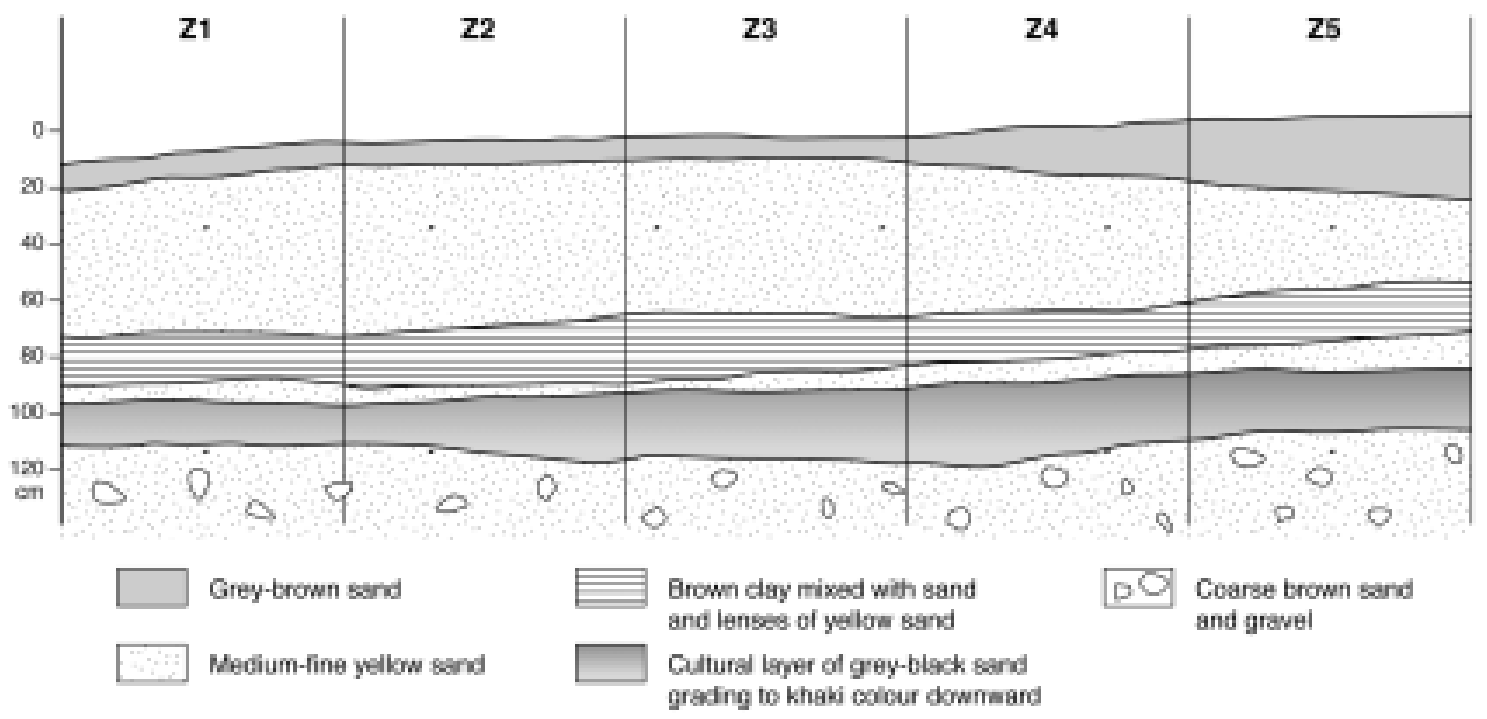

Figure 26. Stratigraphy of the east baulk of row Z in Trench EB97:24. 


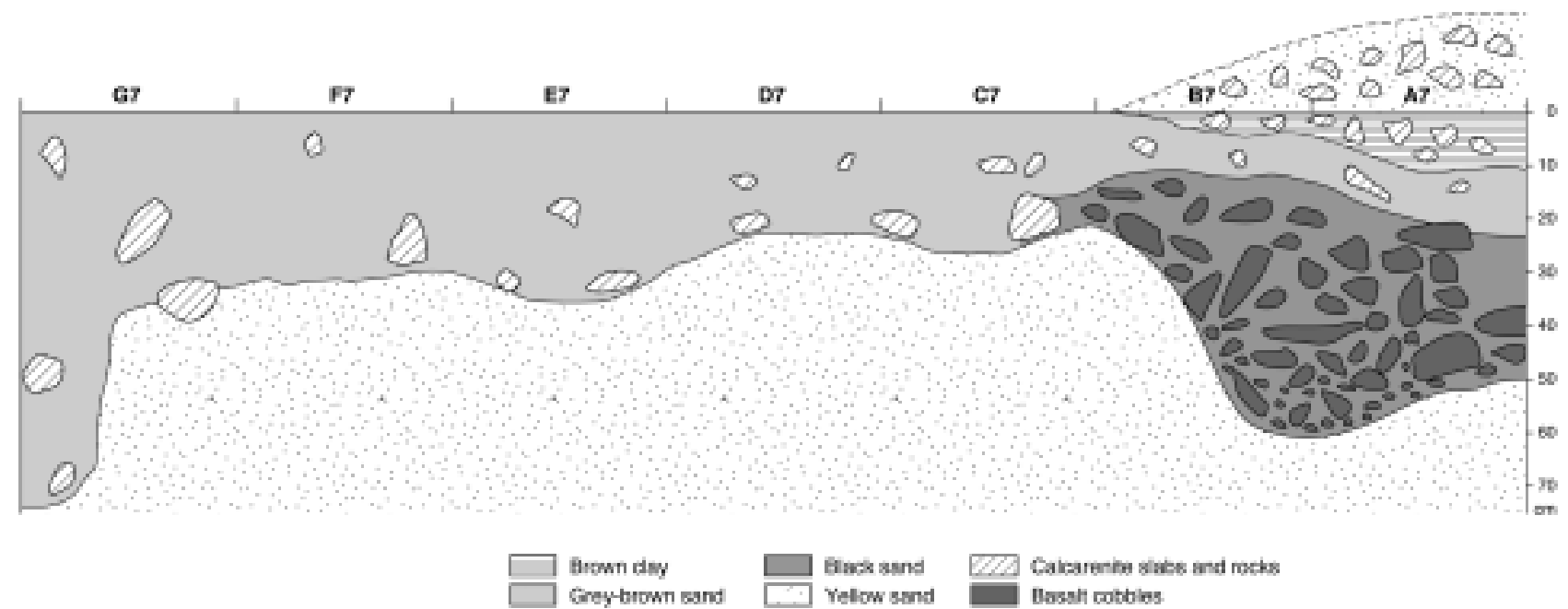

Figure 27. Stratigraphy of the west baulk of row 7 in Trench EB97:23.

Fourth, the virtually level surface of the cultural layer, everywhere that it is encountered, suggests not only that it is in that respect quite typical of a living surface, but perhaps also that it has undergone some natural planation. The remarks in McCarthy (1934: 268) that Mr Rabone found at Emily Bay, "a number of small adzes in process of being fashioned. With them were several hundred flakes that had been chipped off in the shaping of the adzes," suggest that some part of the site was open at that time. Since the Emily Bay dunes were largely unvegetated prior to the establishment of the current plantation, as shown in numerous photos taken from the 1930s onward (S. Quintal collection), it is very probable that wind deflation had periodically exposed parts of the site and planed the surface. It is probably this process which allowed a piece of European ceramic to almost reach the surface of the cultural layer in EB97:24 (square Z2), and which enabled a piece of modern pig mandible to reach the top of the cultural stratigraphy in EB97:23 (see also Anderson, Higham and Wallace, this vol.).

\section{Fieldwork in 1999}

During the 1997 fieldwork we observed considerable numbers of landsnails in all levels of the trenches. Grab samples were taken from the sands above and below the grey sandy cultural level and appeared to show considerable changes. In an attempt to analyse the human impact on the local environment, further samples were taken by $10 \mathrm{~cm}$ sand auger in February 1999. Two sets, each of four samples, were taken adjacent to Trench EB97:23 and another set near EB96:10 (Figs. 13, 20). Two other sets were begun but encountered European disturbance and were abandoned. Two sets of two samples each were taken at Cemetery Bay, one inside and one adjacent to the new quarry. A comparative sample of the modern landsnail fauna was collected from six environmental zones by Dr Winston Ponder, Australian Museum. The analysis of this material is described by Neuweger, White and Ponder, (this vol.).

\section{Additional investigations}

The existence of prehistoric archaeological remains at Kingston, and the recovery of various artefacts, mostly adzes, from elsewhere on Norfolk Island, encourages the view that there may be additional prehistoric sites to be found. Some initial explorations were conducted during the 1997 fieldwork season.

Bomboras Bay. Two small test-pits $(0.3 \times 0.3 \mathrm{~m})$ were dug $20 \mathrm{~m}$ and $30 \mathrm{~m}$ respectively to the north of the creek mouth on a small shelf of fairly level land about $2 \mathrm{~m}$ back from the high tide mark. The first disclosed only $0.5 \mathrm{~m}$ of stiff

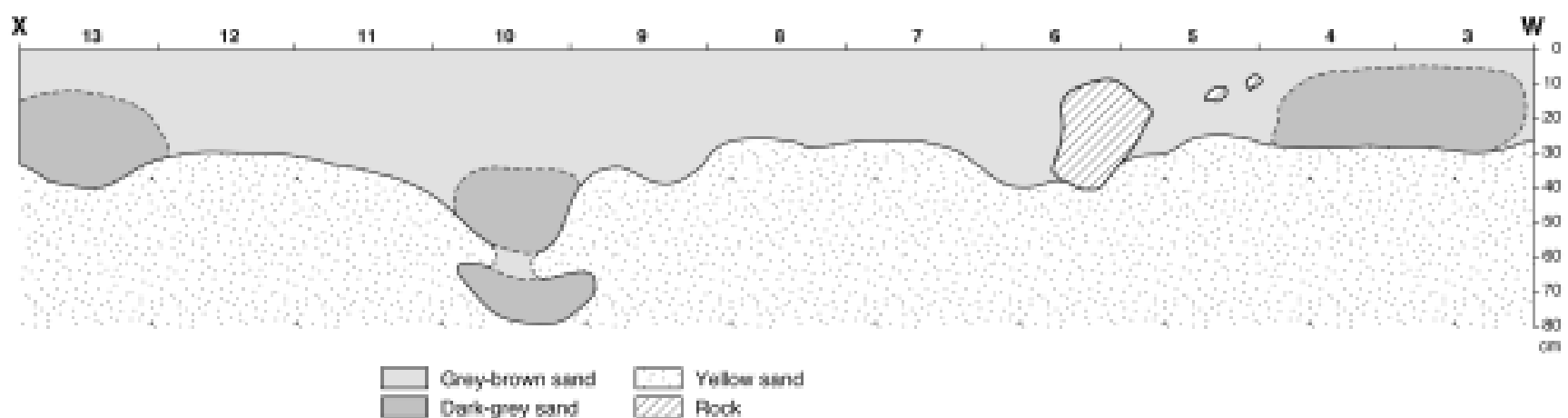

Figure 28. Stratigraphy of the south baulk of row F in Trench EB97:23. Transect WX shown in Anderson and Green (this vol., their fig. 2). 
brown clay above bedrock. The second had $0.3 \mathrm{~m}$ of the same clay above $0.3 \mathrm{~m}$ of orange-yellow calcareous sand resting upon water-rolled boulders. No cultural material was observed.

Ball Bay. There are hearsay accounts of adzes being found at Ball Bay, notably along the eastern side of the bay near the "Melky" trees (Nicolai, pers. comm.). At the main patch of these, located around the coast about $210 \mathrm{~m} \mathrm{SE}$ of the oil depot, a test-pit $(0.3 \times 0.3 \mathrm{~m})$ disclosed $0.45 \mathrm{~m}$ of brown, hard-packed clay lying upon basalt bedrock. A second testpit, a further $22 \mathrm{~m}$ to the east, cut through $0.55 \mathrm{~m}$ of hardpacked clay and clasts of weathered basalt, especially towards the bottom, to encounter $0.37 \mathrm{~m}$ of stone-free, brown clay-loam (probably an old soil horizon) resting upon heavily-weathered basalt boulders. The area on which this test-pit was located is a gently-sloping shelf of ground about $30 \times 10 \mathrm{~m}$ lying immediately behind the boulder beach. The existence of this deeply buried horizon of good soil suitable for settlement should encourage more extensive investigation in future, despite the absence of cultural material in our excavations.

Phillip and Nepean Island. A brief surface inspection of the deeply-eroded surface of Phillip Island produced nothing of archaeological interest. Nepean Island, heavily wooded at European contact, is now under deep grass with occasional wind-sheared white oaks. The ground has been extensively disturbed by muttonbird burrowing. A test-pit $(0.3 \times 0.3 \mathrm{~m})$ was dug on the saddle of the island. It found $0.5 \mathrm{~m}$ of friable, sandy loam resting on calcarenite bedrock. Muttonbird bones occurred, but nothing of cultural origin. A second test-pit was dug on a natural terrace about $15 \mathrm{~m}$ above sea level in the large cove and sand-beach on the NW coast of the island, a reasonably sheltered position. There was $0.6 \mathrm{~m}$ of yellow carbonate sand above calcarenite. Occasional bird and lizard bone appeared natural and there was one small cowrie shell, but nothing which appeared to be of cultural origin.

\section{Conclusions}

The fieldwork of the NIPP has located an extensive prehistoric site in Emily Bay, and shown that, so far at least, this is the only such site of any significance remaining on Norfolk Island. Excavations during 1995-1999 (Fig. 29) show that the Emily Bay site has a single cultural layer containing various features, notably a paved structure, and numerous ovens, with associated midden remains and quantities of flaked basalt.

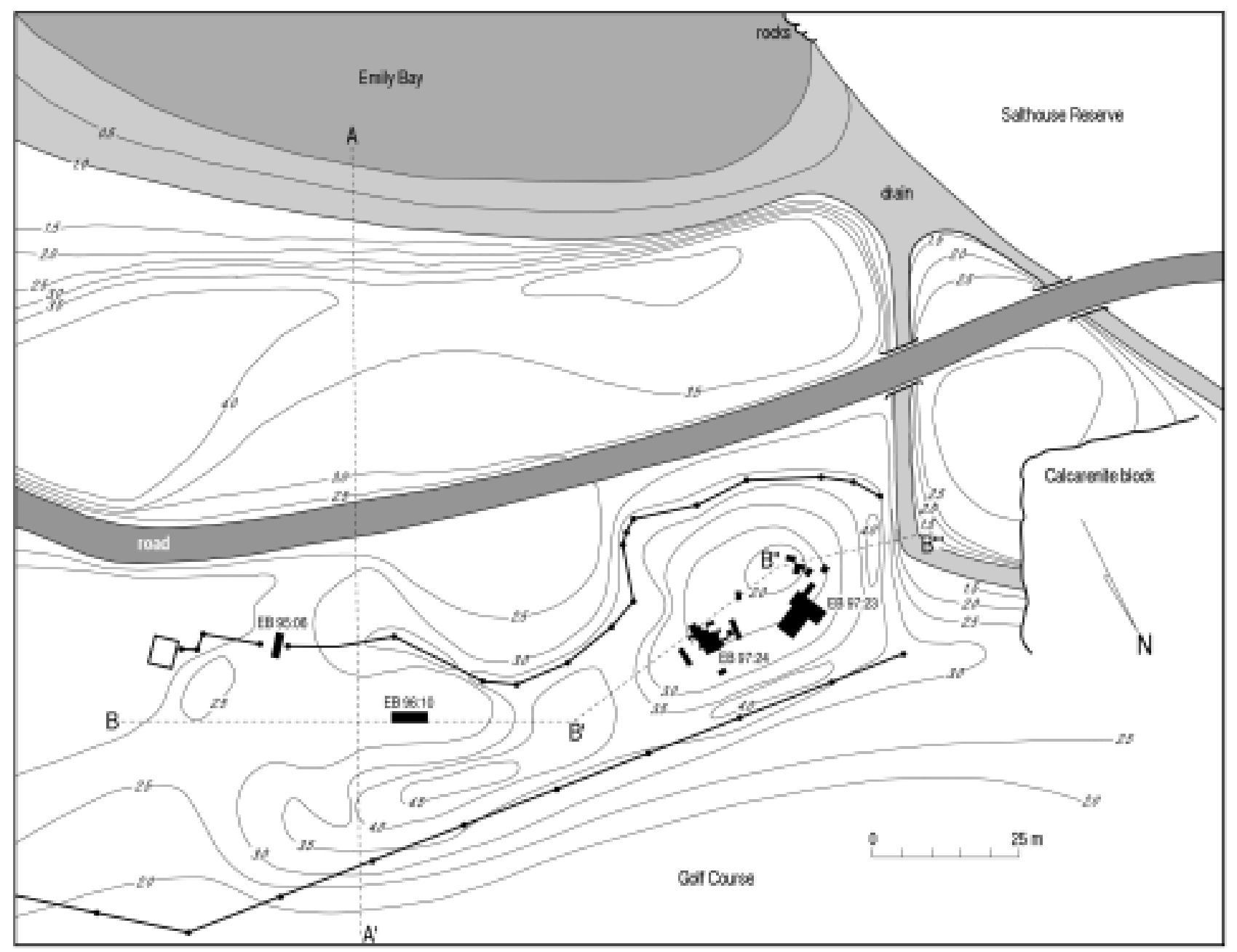

Figure 29. Map of all NIPP excavations at Emily Bay. 
The site is approximately $100 \mathrm{~m}$ long and $30 \mathrm{~m}$ wide on average $\left(3000 \mathrm{~m}^{2}\right)$, but it is now almost certainly rather smaller than it was originally, having been eroded along the seaward side and quite probably also to the east where the dunes are much younger and appear to have filled an area which had been heavily eroded by wind and water. Various agencies of post-depositional disturbance have also compromised the integrity of the cultural layer in many areas. Nevertheless, enough of the site remains in sufficiently original condition to obtain a clear view of the nature of the occupation that it represents.

\section{References}

Anderson, A.J., 1996. Discovery of a prehistoric habitation site on Norfolk Island. Journal of the Polynesian Society 105: 479-486.
McCarthy, F.D., 1934. Norfolk Island: additional evidence of a former native occupation. Journal of the Polynesian Society 43: $267-270$.

Meredith, C.W., J.R. Specht and P.V. Rich, 1985. A minimum date for Polynesian visitation to Norfolk Island, Southwest Pacific, from faunal evidence. Search 16: 304-306.

Nicolai, B., n.d. Diary of fieldwork on Norfolk Island. Unpublished manuscript in author's possession.

Specht, J., 1984. The Prehistoric Archaeology of Norfolk Island. Pacific Anthropological Records 34. Honolulu: Bernice P. Bishop Museum.

Specht, J., 1993. Additional evidence for pre-1788 visits by Pacific Islanders to Norfolk Island, South-west Pacific. Records of the Australian Museum, Supplement 17: 145-157.

Varman, R.V.J., 1990. Cemetery Bay Water Assurance Scheme, Quarry Site 1, Archaeological Report. Unpublished report prepared for the Norfolk Island Government. 
Full-text PDF of each one of the works in this volume are available at the following links :

Anderson and White, vol. eds, 2001, Rec. Aust. Mus., Suppl. 27: 1-143

http://dx.doi.org/10.3853/j.0812-7387.27.2001.1334

Anderson and White, 2001, Rec. Aust. Mus., Suppl. 27: 1-9

http://dx.doi.org/10.3853/j.0812-7387.27.2001.1335

Anderson et al., 2001, Rec. Aust. Mus., Suppl. 27: 11-32

http://dx.doi.org/10.3853/j.0812-7387.27.2001.1336

Anderson et al., 2001, Rec. Aust. Mus., Suppl. 27: 33-42

http://dx.doi.org/10.3853/j.0812-7387.27.2001.1337

Anderson and Green, 2001, Rec. Aust. Mus., Suppl. 27: 43-51

http://dx.doi.org/10.3853/j.0812-7387.27.2001.1338

Marianne et al., 2001, Rec. Aust. Mus., Suppl. 27: 53-66

http://dx.doi.org/10.3853/j.0812-7387.27.2001.1339

Schmidt et al., 2001, Rec. Aust. Mus., Suppl. 27: 67-74

http://dx.doi.org/10.3853/j.0812-7387.27.2001.1340

Smith et al., 2001, Rec. Aust. Mus., Suppl. 27: 75-79

http://dx.doi.org/10.3853/j.0812-7387.27.2001.1341

Matisoo-Smith et al., 2001, Rec. Aust. Mus., Suppl. 27: 81-84

http://dx.doi.org/10.3853/j.0812-7387.27.2001.1342

Holdaway and Anderson, 2001, Rec. Aust. Mus., Suppl. 27: 85-100

http://dx.doi.org/10.3853/j.0812-7387.27.2001.1343

Walter and Anderson, 2001, Rec. Aust. Mus., Suppl. 27: 101-108

http://dx.doi.org/10.3853/j.0812-7387.27.2001.1344

Campbell and Schmidt, 2001, Rec. Aust. Mus., Suppl. 27: 109-114

http://dx.doi.org/10.3853/j.0812-7387.27.2001.1345

Neuweger et al., 2001, Rec. Aust. Mus., Suppl. 27: 115-122

http://dx.doi.org/10.3853/j.0812-7387.27.2001.1346

Macphail et al., 2001, Rec. Aust. Mus., Suppl. 27: 123-134

http://dx.doi.org/10.3853/j.0812-7387.27.2001.1347

Anderson and White, 2001, Rec. Aust. Mus., Suppl. 27: 135-141

http://dx.doi.org/10.3853/j.0812-7387.27.2001.1348 